\title{
Assessment of seismic strengthening solutions for existing low-rise RC buildings in Nepal
}

\author{
Hemchandra Chaulagain ${ }^{1,2 a}$, Hugo Rodrigues ${ }^{* 3}$, Enrico Spacone ${ }^{4 b}$ \\ and Humberto Varum ${ }^{5 c}$ \\ ${ }^{1}$ Civil Engineering Department, University of Aveiro, 3810-193 Aveiro, Portugal \\ ${ }^{2}$ Oxford College of Engineering and Management, Gaindakot, Nawalparashi, Nepal \\ ${ }^{3}$ School of Technology and Management, Polytechnic Institute of Leiria, Leiria, Portugal \\ ${ }^{4}$ University of Chieti-Pescara, Department PRICOS - Architettura, 65127 Pescara, Italy \\ ${ }^{5}$ Department of Civil Engineering, Faculty of Engineering, University of Porto, Porto, Portugal
}

(Received February 28, 2014, Revised August 19, 2014, Accepted August 29, 2014)

\begin{abstract}
The main objective of this study is to analytically investigate the effectiveness of different strengthening solutions in upgrading the seismic performance of existing reinforced concrete (RC) buildings in Nepal. For this, four building models with different structural configurations and detailing were considered. Three possible rehabilitation solutions were studied, namely: (a) RC shear wall, (b) steel bracing, and (c) RC jacketing for all of the studied buildings. A numerical analysis was conducted with adaptive pushover and dynamic time history analysis. Seismic performance enhancement of the studied buildings was evaluated in terms of demand capacity ratio of the RC elements, capacity curve, inter-storey drift, energy dissipation capacity and moment curvature demand of the structures. Finally, the seismic safety assessment was performed based on standard drift limits, showing that retrofitting solutions significantly improved the seismic performance of existing buildings in Nepal.
\end{abstract}

Keywords: RC buildings; non-linear analysis; retrofitting; shear wall; steel bracings; RC jacketing

\section{Introduction}

Nepal is located in a seismically active Himalayan region with a long history of devastating earthquakes. Amongst the major earthquakes in recorded history, the Great Bihar-Nepal Earthquake of 1934 with a maximum intensity of $X$ (MMI) caused extensive damage in the Kathmandu Valley (Pandey and Molnar 1988). The total death toll in Nepal was 8,519, from which 4,296 occurred in the Kathmandu Valley alone. In this earthquake, about $19 \%$ of the building stock collapsed and 38\% experienced significant damage just in the Kathmandu Valley (Rana 1935). The past study indicated that the human and economic losses due to earthquakes are directly related with the development index of a country (Erdik and Durukal 2008). As an

*Corresponding author, Senior Lecturer, E-mail: hugo.f.rodrigues@ipleiria.pt

${ }^{\mathrm{a}}$ Lecturer

${ }^{\mathrm{b}}$ Full Professor

${ }^{c}$ Full Professor

Copyright $\odot 2015$ Techno-Press, Ltd. 
underdeveloped country, earthquake consequences in Nepal might be more tragic than what was observed in the developed countries. In fact, the social and economic disruption as a result of earthquakes depends on seismic vulnerability of structures. In this context, seismic evaluation and strengthening of seismically deficient structure is the first basic procedure for reducing potential losses stemming from future earthquakes.

Over the last few decades, RC building construction in Nepal has rapidly increased, replacing other construction materials, like adobe, brick and stone buildings with mud mortar, brick and stone buildings with cement mortar and wooden buildings in all over the country (JICA 2002). Most of RC buildings are constructed by reinforced concrete frames with infill masonry panels. These buildings can be classified as engineered and non-engineered, based on their design and construction practices. Non-engineered buildings offered insufficient capacity, lacked ductile detailing and were poorly constructed and have limited durability (NSET 2009). On the contrary, engineered buildings are designed/ constructed considering the standard engineering guidelines. Most of the engineered buildings also do not possess adequate lateral strength, stiffness, and ductility during an earthquake due to the design and construction defects, modifications in codes of practice and standards, environmental effects, changes in their usage and loading conditions and the need to increase the number of floors. Structural deficiencies associated with the absence of ties in beam column joints, inadequate confinement near beam column joints, inadequate lap lengths, low concrete strength, improperly anchored ties, irregularities in plan and elevations, irregular distribution of loads and structural elements, soft storey effects, short column effects, strong beam-weak column connections, etc. are common in RC structures in Nepal and the surrounding areas (Bothara and Hicyilmaz 2008, Chaulagain et al. 2014).

It is, therefore, of primary importance to strengthen the existing RC buildings in order to prevent the resulting loss of lives and property due to future earthquakes. The available strengthening solutions can be classified into two groups as: (i) conventional methods, and (ii) innovative response modification methods (RMMs). In conventional methods, structures are retrofitted either by reducing the drift or increasing the ductility (Moehle 2000, Varum et al. 2013a). The former scheme is implemented by the addition of new structural elements, which improve the strength and stiffness of the system. Alternatively, local strengthening of the lowductility structural elements, which deteriorate the stability of the structure, may be an economical solution for buildings with a limited number of deficient elements. Fig. 1 shows the typical seismic performance of existing non-ductile structures versus structures designed according to performance based seismic engineering. It shows that, upgrading the seismic performance of the existing structures can be achieved by increasing the capacity of the structure with or without reducing its drift. Increasing the capacity by reducing the structure's drift at the same peak ground acceleration level can be achieved by increasing the stiffness of the buildings. Increasing the structure's ductility capacity without reducing the drift at the same PGA level can be achieved by increasing the ductility capacity of the structural elements of the building without altering their stiffness (Galal and Sokkary 2009). Innovative RMMs on the other hand include techniques such as installing seismic isolation devices or dampers in the building. These devices are intended to modify the seismic response of the building so as to alleviate the effect of the seismic forces. Several retrofitting applications using RMMs exist in many parts of the world. These methods usually do not require heavy demolition or construction work when used for seismic retrofitting. Nevertheless, such methods are generally costly to implement (Disamo and Manfredi 2010, Calvi 2013).

The selection of the optimum retrofit solution is a complex procedure that depends on several 
technical and socio-economical parameters. The retrofitting solutions also depend on the target performance level of the structures which is based on selective or overall modification of stiffness, strength, and ductility of structures (Thermou et al. 2007). Considering the importance of structure, target life, extent of deficiency of the structures, the economic viability, availability of the materials and technical resources, and the expected life after retrofitting; RC shear wall, steel cross bracing and RC jacketing are proposed as the practically feasible and economically viable retrofitting solutions for existing vulnerable RC buildings in Nepal. These proposed retrofitting solutions are effective lateral force resisting systems and significantly increases the seismic performance of the structures (Calvi 2013, Fardis et al. 2012). Added concrete walls are very popular for seismic retrofitting of concrete buildings. A simple and cost-effective way of adding walls is to infill with reinforced concrete (RC) selected bays of the existing frame, especially on the perimeter (Fardis et al. 2013). A steel bracing system also has several advantages that make it another effective alternative for providing additional lateral stiffness and strength to the structure (Varum et al. 2013b). These are easy to apply, and they can be applied externally without disturbance to the building's occupants. The steel has a high strength-to-weight ratio, thus the additional mass added to the structure is less, compared to the introduction of a RC structural wall. $\mathrm{RC}$ jacketing on the other hand, is effective in correcting specific deficiencies in strength and /or deformation capacity in the structures. It significantly improves the shear capacity, flexural strength and ductility of damaged or weak members in the structures (NSET 2009, Rodrigues et al. 2012).

In this context, this paper presents an attempt towards the evaluation of seismic vulnerability of both non-engineered and engineered RC buildings in Nepal and proposed some practical solutions to reduce it. The evaluation process helps in deciding whether the safety provided by the building is adequate or not. To this, primary and detailed evaluations of the structures were performed using the standard procedures. Based on the evaluation results, strengthening solutions were applied to all the studied buildings and study the effectiveness of each retrofitting solutions through nonlinear analysis. Adaptive pushover and dynamic time history analysis were applied to evaluate the seismic performance enhancement of the rehabilitated structures. For adaptive pushover analysis response spectrum provided in code was used whereas the artificial ground motion records were used for dynamic time history analysis. Finally, the seismic safety assessment of rehabilitated structure was performed considering the standard guidelines.
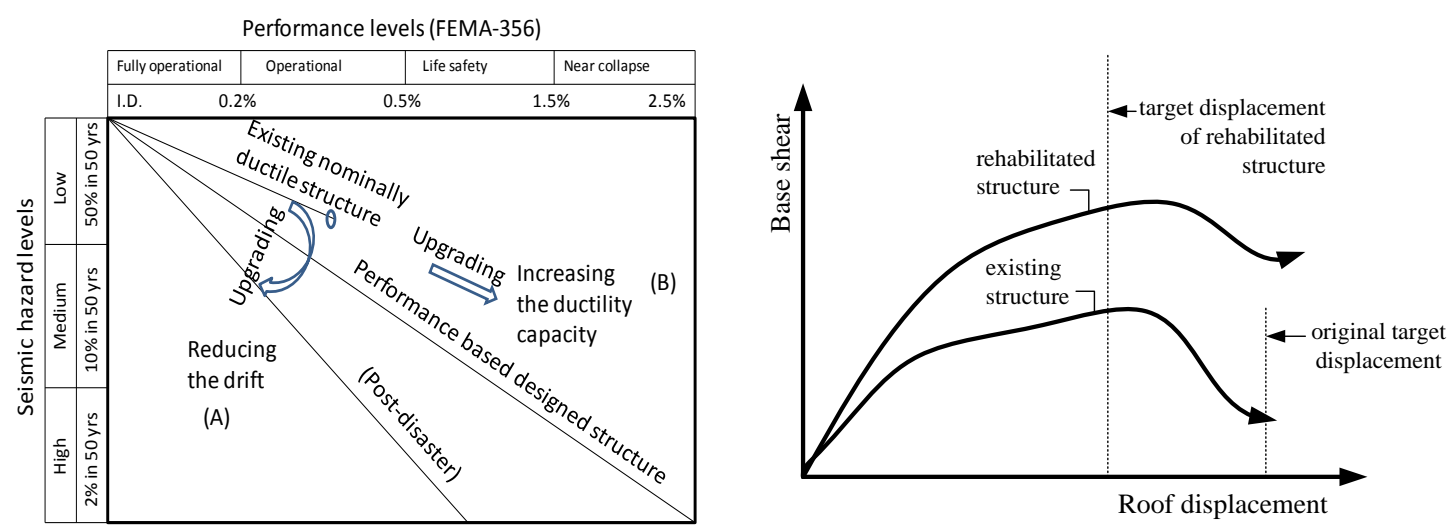

Fig. 1 Seismic performance of existing structures and possible ways of upgrading (Galal and Sokkary 2009) 


\section{Case study}

\subsection{Description of the case study building structures}

In this study, four existing reinforced concrete structures in Nepal were selected for analysis. The selection of studied buildings were based on the detailed information collected from previous studies, private practitioners, design offices, public institutions, and a field survey in different localities in Nepal. All of the building's configurations are typical of seismically-active regions, where the vast majority of dwellings are RC buildings with similar characteristics (Chaulagain et al. 2013).

The first type of study buildings are representative of non-engineered construction, namely: a) RC1 building model and b) RC2 building model, and second type of buildings are engineered constructions, denoted as: c) RC3 building model and d) RC4 building model. The engineered building consists of RC frame assembly of cast-in-place concrete beams and columns. Floor and roof framing consists of cast-in-place concrete slabs. Lateral forces are resisted by concrete moment frames that develop their stiffness through monolithic beam-column connections. Some of the newly constructed reinforced concrete buildings are likely to be of this type whilst, nonengineered buildings are designed/ constructed without following the standard engineering guidelines. Most of this building construction mechanism was based on owner built construction. This category also includes the buildings that have architectural drawings prepared by engineers. These buildings are constructed with light reinforced concrete frames with masonry infill which present insufficient strength, lacked of ductile detailing, poorly constructed, and have limited durability (Chaulagain et al. 2014). Due to the poor confinement of lap splices, lack of shear reinforcement in the beam-column joints and inadequate embedment length of the beam bottom reinforcement at the columns, these frames behave in a non-ductile manner and may fail in brittle failure modes. Plan, three-dimensional model, and cross sectional detailing of all the building models are summarized in Figs. 2-5.

The first two buildings are non-engineered structure with square (RC1) and rectangular plan configuration (RC2), built in urban area in Nepal. All these types of buildings have $3 \mathrm{~m}$ interstorey height in all storeys. RC1 building model has 4 rooms per storey where as the room number is 6 in RC2 building model. RC1 building model has $9 \mathrm{~m} \times 9 \mathrm{~m}$ plan area with three moment resisting systems for both in $X$ and $Y$ directions. In first and second storey, the dimensions of the sections of all the columns are $230 \times 300 \mathrm{~mm}^{2}$, of all the beams are $230 \times 350 \mathrm{~mm}^{2}$ and at the top storey such dimensions are respectively $230 \times 230 \mathrm{~mm}^{2}$ and $230 \times 350 \mathrm{~mm}^{2}$. Likewise, in the RC2 building model, the lateral load resisting elements in $X$-direction consist of three moment resisting frames, and in $Y$-direction the frames are four. The building dimension in the plan is $10.5 \mathrm{~m} \times 8 \mathrm{~m}$. Similarly, the remaining two case study buildings are engineered RC-MRF structure with regular (RC3 model) and irregular plan configuration (RC4 model), recently constructed in Nepal. The inter-storey height of these buildings is $2.85 \mathrm{~m}$ in all storeys. Building model RC3 having plan area $9.6 \mathrm{~m} \times 7.9 \mathrm{~m}\left(75.84 \mathrm{~m}^{2}\right)$, measured from the column centre lines. Four identical moment resisting frames in $X$ and $Y$-directions act as a lateral load resisting elements. Building model RC4 has a trapezoidal plan area measuring $70.8 \mathrm{~m}^{2}$ which has three and four moment resisting frames in $X$ and $Y$ direction respectively. Furthermore, in non-engineered buildings $8 \mathrm{~mm} \emptyset$ Stirrups @ 200 $\mathrm{mm} \mathrm{c/c}$ throughout the length of beam and columns were used whereas for engineered buildings 8 mm Østirrups@100 mm c/c throughout the length of beam and columns were used. The material properties are assumed to be identical for all the four building models throughout the height. The 


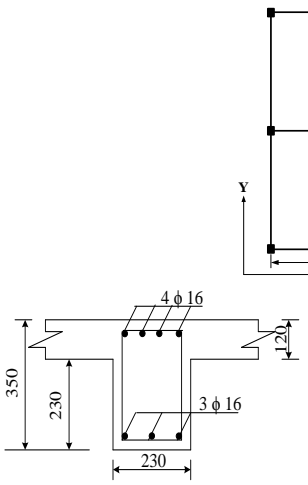

1st \& 2nd

floor beam
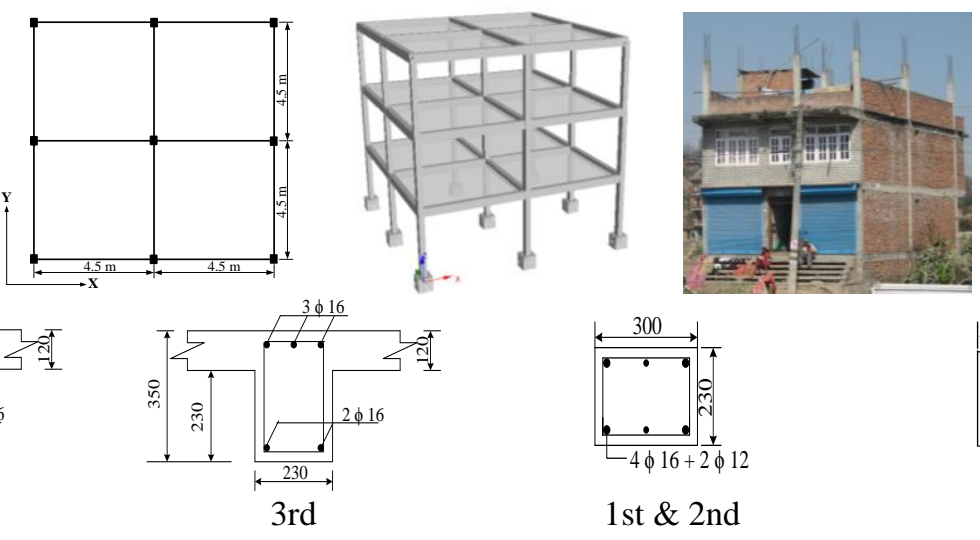

floor beam

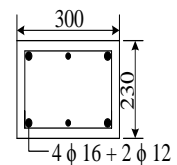

1st \& 2nd

storey column

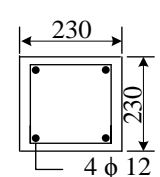

top storey column

Fig. 2 Plan, 3-D model and cross-sectional detailing of building model RC1
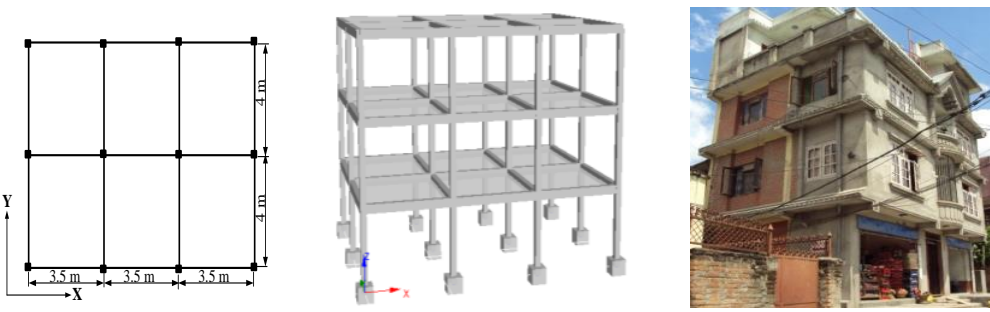

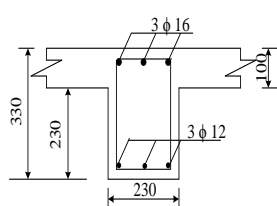

1st \& 2nd

floor beam

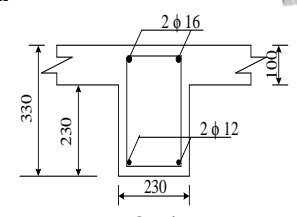

3rd

floor beam

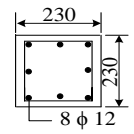

interior columns

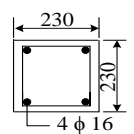

corner/façade column

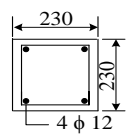

top

Fig. 3 Plan, 3-D model and cross-sectional detailing of building model RC2

Table 1 Material properties for case study buildings

\begin{tabular}{cc}
\hline \hline Materials & Characteristics \\
\hline Reinforcing steel yield strength, $f_{y}$ & $415 \mathrm{MPa}$ \\
Concrete compressive strength, $f_{c}$ & $20 \mathrm{MPa}$ \\
Brick on peripheral beams & $230 \mathrm{~mm}$ thick \\
Brick wall on internal beams & $115 \mathrm{~mm}$ thick \\
Density of brick masonry with plaster & $20 \mathrm{kN} / \mathrm{m}^{3}$ \\
Density of reinforced concrete & $25 \mathrm{kN} / \mathrm{m}^{3}$ \\
\hline
\end{tabular}

Table 2 Loadings for numerical analysis of structure

\begin{tabular}{cc}
\hline \hline Loading characteristics & Loading \\
\hline Live load on roof & $1.5 \mathrm{kN} / \mathrm{m}^{2}$ \\
Live load on floors & $2 \mathrm{kN} / \mathrm{m}^{2}$ \\
Roof and floor finishing & $1 \mathrm{kN} / \mathrm{m}^{2}$ \\
\hline
\end{tabular}



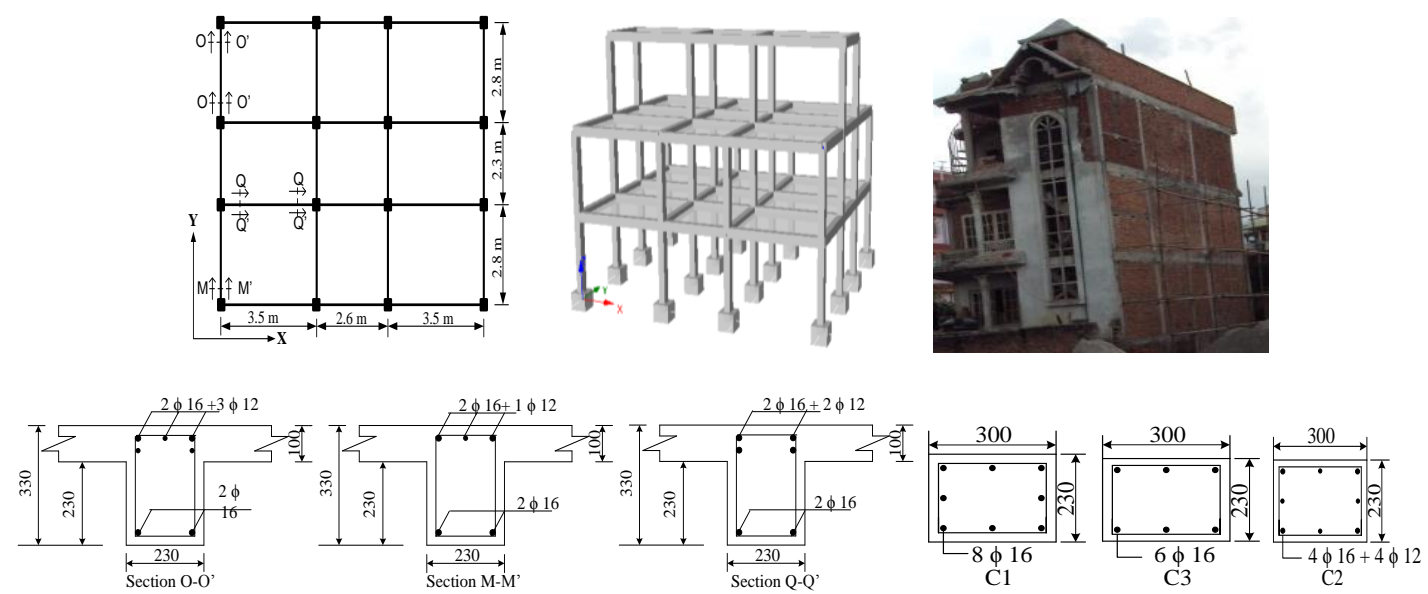

Fig. 4 Plan, 3-D model and cross-sectional detailing of building model RC3
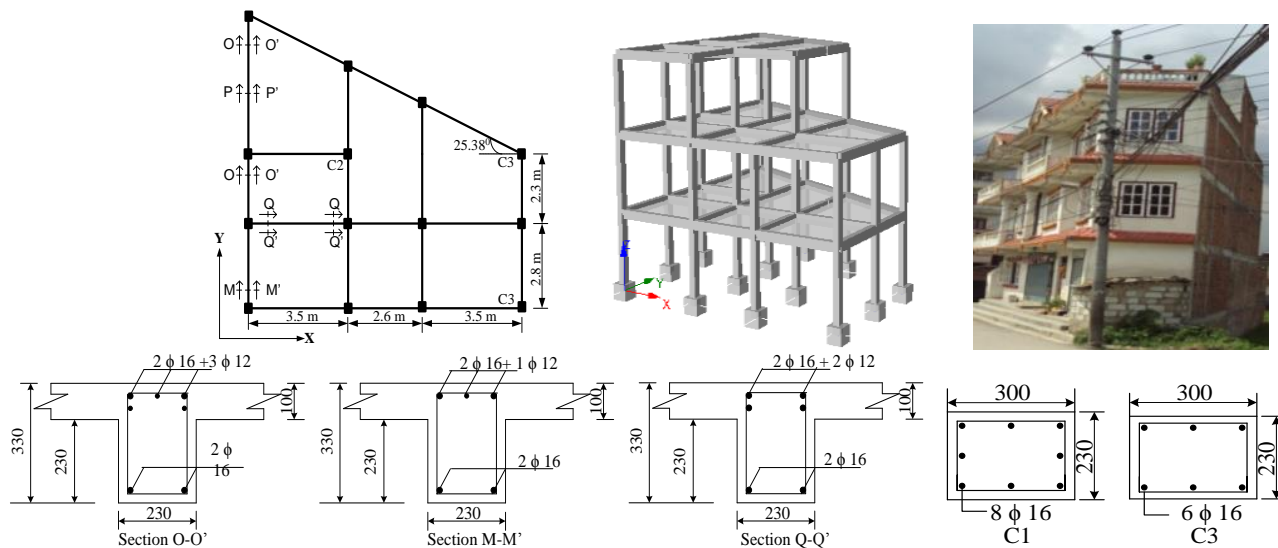

Fig. 5 Plan, 3-D model and cross-sectional detailing of building model RC4

Note: All dimensions are in mm unless stated otherwise

: All the interior, façade and corner columns of building models RC3 and RC4 are C1, C2, and C3 respectively unless stated otherwise.

Table 3 Seismic performance evaluation of existing beam and column elements

\begin{tabular}{|c|c|c|c|c|c|c|}
\hline \multirow{2}{*}{ S. N } & \multirow{2}{*}{ Check } & \multicolumn{4}{|c|}{ Demand capacity ratio (DCR) } & \multirow{2}{*}{ Remarks } \\
\hline & & $\mathrm{RC} 1$ & $\mathrm{RC} 2$ & $\mathrm{RC} 3$ & $\mathrm{RC} 4$ & \\
\hline 1 & $\begin{array}{l}\text { Shear stress in RC frame } \\
\text { column }\end{array}$ & 0.82 & 0.86 & 0.44 & 0.43 & $\begin{array}{c}>0.4 \& \min \\
0.1 \sqrt{f_{c k}(\mathrm{NG})}\end{array}$ \\
\hline 2 & $\begin{array}{c}\text { Axial stress in moment frame } \\
\text { at base }\end{array}$ & 0.22 & 0.34 & 0.24 & 0.29 & $<1(\mathrm{~S})$ \\
\hline 3 & $\begin{array}{l}\text { Moment of resistance of beam } \\
\text { in compression }\end{array}$ & 1.26 & 1.31 & 1.02 & 1.14 & $>1(\mathrm{NG})$ \\
\hline 4 & $\begin{array}{c}\text { Moment of resistance of beam } \\
\text { in tension }\end{array}$ & 1.98 & 3.10 & 1.35 & 1.44 & $>1(\mathrm{NG})$ \\
\hline 5 & Column flexural capacity & 6.58 & 5.99 & 1.24 & 1.35 & $>1(\mathrm{NG})$ \\
\hline 6 & Column beam capacity ratio & 0.40 & 0.35 & 1.00 & 1.02 & $<1.2(\mathrm{NS})$ \\
\hline
\end{tabular}


characteristics of material properties and loading on the building structures are presented in Tables 1 and 2.

\subsection{Seismic assessment of elements in the studied building structures}

The past earthquakes in Nepal, as well as the recent earthquakes in different regions in the world and resulting human and economic losses, have highlighted the structural inadequacy of buildings in carrying expected seismic loads. Thus, there is an urgent need to assess the existing buildings and check seismic resistance. There are limited guidelines available for the assessment of the strength, expected performance, and safety of existing buildings, as well as for carrying out the necessary rehabilitation. FEMA-310 (1998) document prescribes a three-tiered process of increasing detail and reducing the margin of safety for the seismic evaluation of existing buildings: a) screening phase, b) evaluation phase, and c) detailed evaluation phase. The ASCE/SEI 31-03 provides a standard procedure for the seismic evaluation of existing buildings (ASCE 2003). Eurocode 8 (2004) evaluation process consists of verification of the seismic resistance of an existing buildings and recommends for the repair/strengthening of the buildings. The SERC (2002) report recommends the structural score based on seismic zone, age of the building, number of stories, eccentricity, soil types, foundation types, structural deficiencies, and a response reduction factor for the seismic performance evaluation of the existing buildings. Rai (2005) classify the evaluation procedures into two categories: (a) configuration-related checks (e.g., load path, weak story, soft story, geometry, effective mass, torsion, pounding etc.) and (b) strength related checks (force levels for strength analysis, shear stress check, axial stress check etc.).

In this study, the primary and detailed seismic assessment of selected structures is performed using IITK-GSDMA guidelines for seismic evaluation and strengthening of buildings (Rai 2005). The result of structural evaluation is presented in Table 6.1. In Table 6.1; NG, S, and NS represent for the structural check as not good, satisfied and not satisfied respectively. In most of the cases, the demand capacity ratio (DCR) of shear stress, flexural capacity of the column, and the beam column capacity ratio of the buildings do not satisfy the minimum criteria provided by the standard guidelines. This implies that the safety of the existing buildings is inadequate and hence retrofitting is necessary. The proposed technically feasible and economically viable retrofitting solutions will be discussed in the upcoming sections.

\section{Strengthening solutions and modelling strategies}

\subsection{Structural modelling aspect}

In the present study, the numerical analysis of RC shear wall, steel cross bracing, and RC jacketing were performed using SeismoStruct (2006) computer program which is capable of predicting the large displacement behavior of space frames under static or dynamic loading, taking into account both geometric nonlinearities and material inelasticity. The accuracy of this software in non-linear analysis of the framed structures was compared with the experimental results during 'concrete column blind prediction contest 2010' (UCSD, San Diego, USA) and '15 WCEE blind test challenge' (LNEC, Lisbon, Portugal). Moreover, Rodrigues et al. (2011), Smyrou (2011) also perform the non-linear analysis of the RC building models and compared the results with experimental one. In both of the cases, result obtained from the SeismoStruct software was the 
Table 4 Seismic risk scenarios for various return periods (Parajuli 2009)

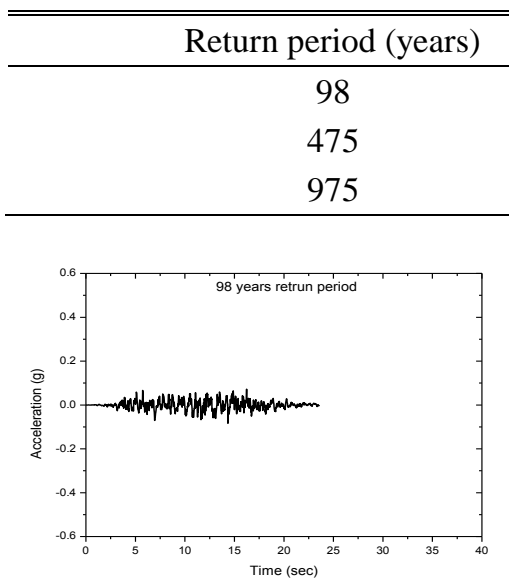

i)

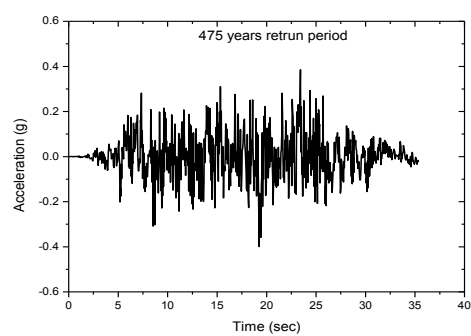

ii)
Peak ground acceleration $\left(\mathrm{m} / \mathrm{s}^{2}\right)$

$0.07 \mathrm{~g}$

$0.40 \mathrm{~g}$

$0.51 \mathrm{~g}$

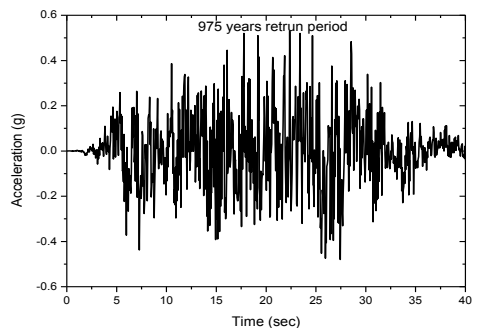

iii)

(a) Time history data for: (i) 98 years, ii) 475 years and iii) 975 years return period

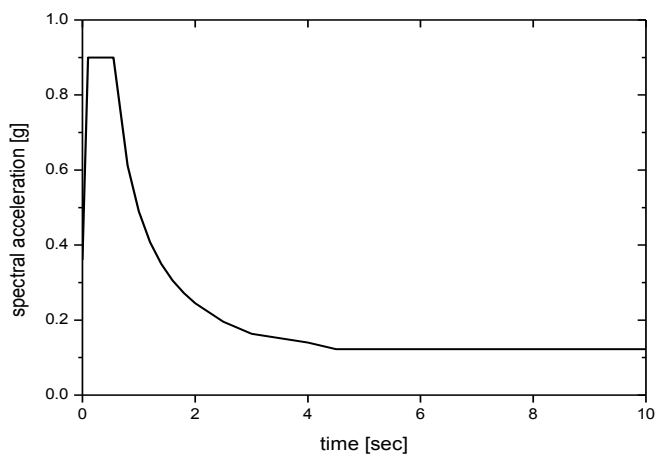

(b)

Fig. 6 (a) Time history and (b) response spectrum used for numerical analysis of building models

good correlation with the experimental results.

A lumped plasticity model for the RC frame elements was adopted during numerical analysis. The structural analysis was based on bare frame building modelling with three-dimensional models. In the analyses performed in this paper, half of the larger dimensions of the cross-section is considered as the plastic hinge length with fibre discretisation at the section level.

The concrete model used is based on the Madas and Elnashai (1992) uniaxial model, which follows the constitutive law proposed by Mander et al. (1988). The cyclic rules included in the model for the confined and unconfined concrete is according with Martinez-Rueda (1997), Elnashai and Elghazouli (1993). The confinement effects provided by the transverse reinforcement were considered through the rules proposed by Mander et al. (1988), whereby constant confining pressure is assumed throughout the entire stress-strain range, traduced by the increase in the peak value of the compression strength and the stiffness of the unloading branch.

The uniaxial model proposed by Menegotto and Pinto (1973), coupled with the isotropic hardening rules proposed by Filippou et al. (1983), was adopted for the reinforcement steel representation in these analyses. This steel model does not represent the yielding plateau 
characteristic of the mild steel virgin curve. The model takes into account the bauschinger effect, which is relevant for the representation of the columns' stiffness degradation under cyclic loading.

In this study, a nonlinear analysis of the building models is performed with adaptive pushover and dynamic time history analyses. For the adaptive pushover analysis, a response spectrum provided in Indian seismic code is used (IS 1893 2002). It is due to the fact that Nepal building code does not possesses sufficient data required for standard design consideration. Currently, most of the engineered buildings in Nepal have been designed based on the Indian seismic code. Earthquake ground motion histories are important for dynamic analyses of the structures. Though, many earthquakes have been reported in the history of Nepal, no accelerations have been recorded. Due to the lack of actual time history data in Nepal, the dynamic time history analysis was performed with generated time history data. For this, three different artificially generated time history records in Nepal, with increasing peak ground acceleration (PGA) value ranging from 0.07 $\mathrm{g}$ to $0.51 \mathrm{~g}$, were used (Parajuli 2009). During the inelastic time history analyses, the scaling of the time history data was employed for the intermediate values. Artificially generated PGA for various return periods are tabulated in Table 4 and presented in Fig. 6.

\subsection{Seismic retrofitting solutions}

The term "retrofit strategy" refers to any option of increasing the strength, stiffness, and ductility of the members, or of the whole building. The possible intervention options need to be selected based on the building typology and the expected performance of the building after retrofitting. The selection of probable intervention options also depend on: a) requirements to comply to the building code for design, materials and construction, b) compatibility of the solution with the functional requirements of the structure, c) possible cost implication, d) indirect costs of retrofitting such as relocation costs, e) availability of construction techniques (materials, equipment and workmanship) in the construction industry, f) enhancement of the safety of the building after the intervention of the selected option, and $\mathrm{g}$ ) aesthetic view of the building (NSET 2009, Calvi 2013). Therefore, by considering the aforementioned requirements, RC shear wall, steel bracing, and RC jacketing are selected as retrofitting solutions for seismically deficient RC buildings in Nepal.

The redesign of the buildings were based on the Indian standard code, considering the seismic design with ductile detailing, considering the building located in the seismic zone $\mathrm{V}$ (which is liable to shaking intensity of IX and higher) and medium soil type. The seismic analysis was performed using the seismic coefficient method (IS 1893 2002). The effect of finite size of joint width (e.g., rigid offsets at member ends) was not considered in the analysis. However, the effect of shear deformation was considered. Beams and columns are designed with the IS 13920 (1993) recommendations. The loadings and load combinations are defined based on the Indian standard codes. Due to similarity in seismic hazard in the northern India and Nepal along the Himalayan belt and similar soil types, the zone factors indicated in Indian seismic code was considered in this study. The descriptions of each of the retrofitting methods applied in this study are summarised in the following sections:

\subsubsection{Reinforced concrete shear wall}

$\mathrm{RC}$ shear walls can provide the required lateral stiffness and strength for resisting lateral loads due to earthquakes, and hence several studies and experimental works were done to investigate their behaviour under lateral loads. This enables the designers to predict their seismic responses in 
a certain buildings when subjected to severe ground motion (Fardis et al. 2013, Kaplan et al. 2011). The technique of adding new shear walls is often taken as an appropriate solution for improving the seismic performance of existing structures. The new structural walls protect the existing elements by controlling the global drift. Such shear walls not only significantly increase the lateral stiffness, but also relieve the existing frames from the lateral loads (Varum 2003). Adding shear walls to complete the load path can also correct discontinuities. Therefore, it is usually used for the retrofitting of non-ductile reinforced concrete frame buildings. However, it should also be pointed out that adding infill shear walls will decrease the natural period, which can increase the demand considerably.

In this study, each building model is braced by four shear walls. RC walls are coupled at each storey level by a RC slab. All of the walls have a width of $0.15 \mathrm{~m}$ and are designed according to the standard code. The Mander concrete model is used to define the concrete materials used in the $\mathrm{RC}$ rectangular sections for modelling. The section has two nodes at the top and bottom of the boundaries. The Monegotto-Pinto steel model is used to define the steel material used for the wall reinforcement. Seismosoft structural modelling software is used for the modelling of the shear wall. The walls are modeled using a 3-D force-based inelastic frame element with four integration sections. The number of fibres used in the section equilibrium computations is set to 200 . The shear wall was designed using IITK-GSDMA guidelines for seismic evaluation and strengthening of buildings (Rai 2005). Based on the analysis, the two curtains of reinforcement with no boundary elements are used. Four bars of $\emptyset 12 \mathrm{~mm}$ diameter in two layers at either end are provided for design purposes. The location, orientation and detailing of the shear wall is presented in the Fig. 7.

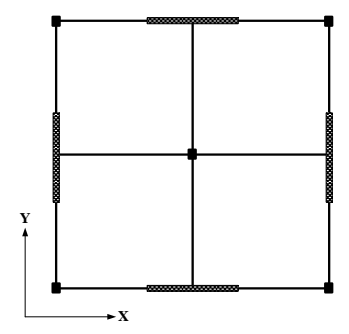

(a)

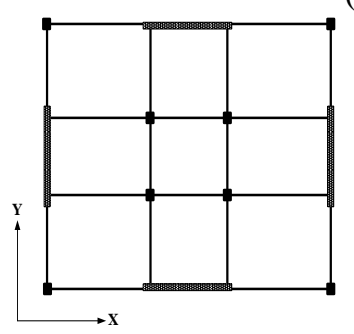

(c)
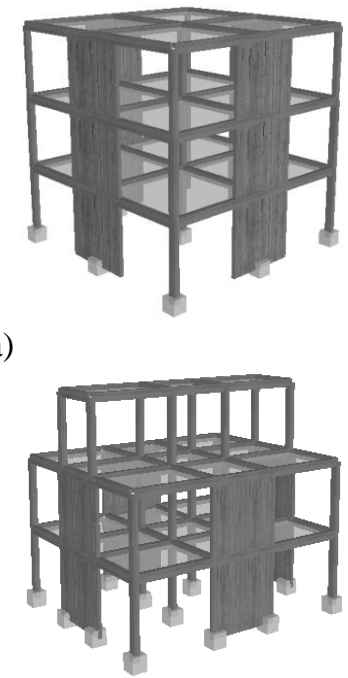

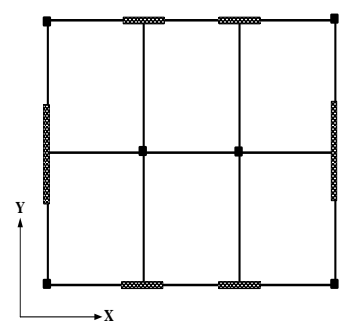

(b)

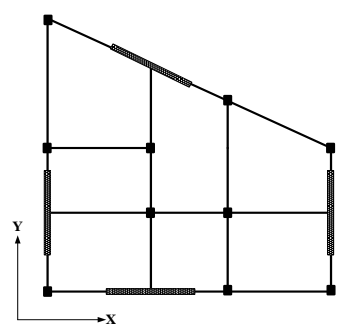

(d)
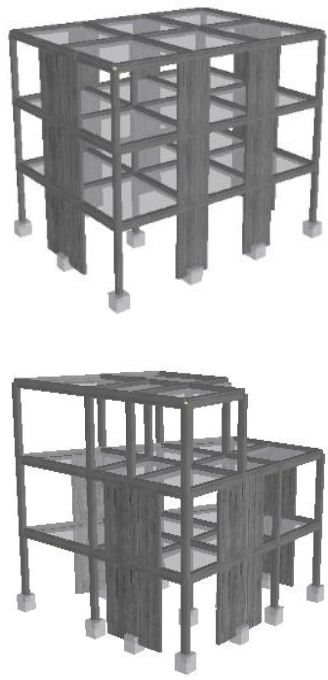

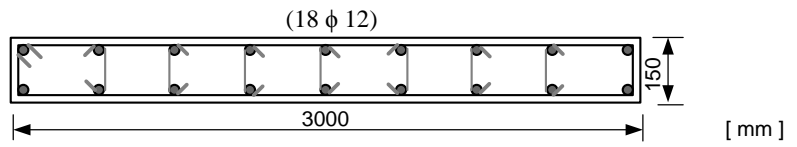

(e)

Fig. 7 Location and orientation of shear walls for building models: (a) RC1, (b) RC2, (c) RC3, (d) RC4 and (e) detailing of the shear wall 

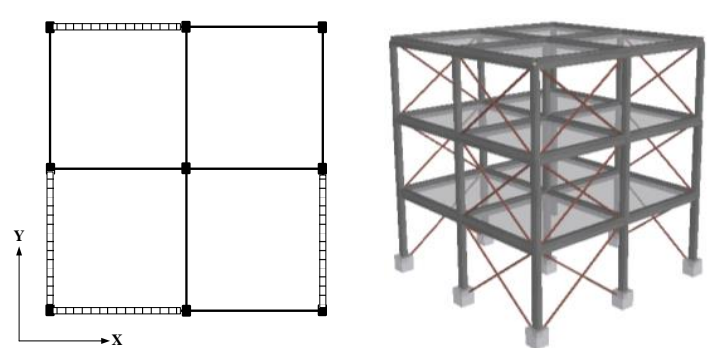

(a)

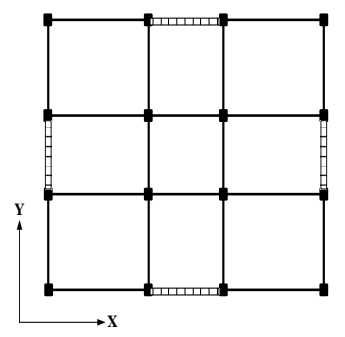

(c)

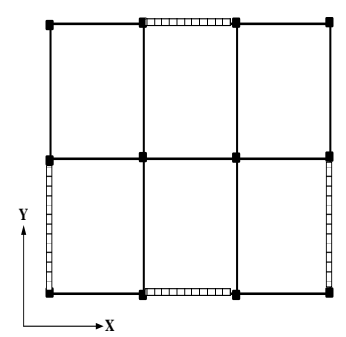

(b)
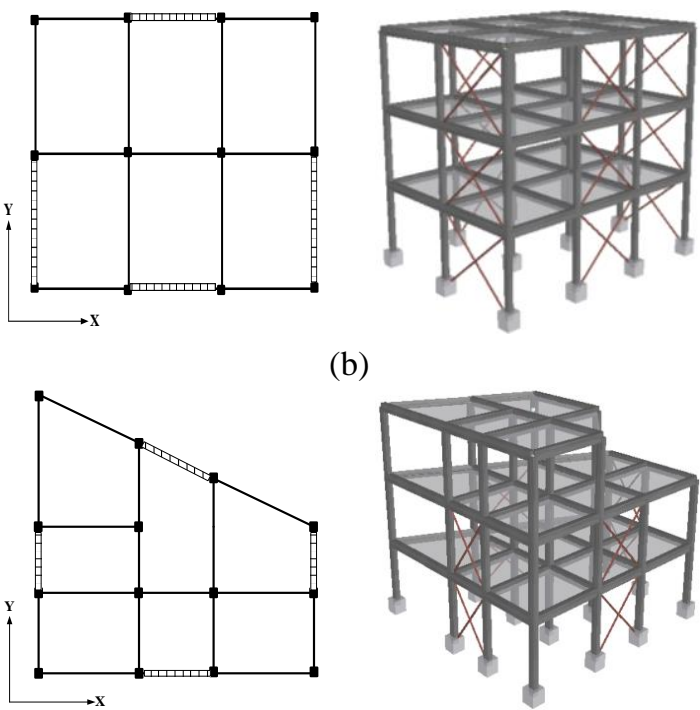

(d)

Fig. 8 Location and orientation of steel $X$-bracing for building models: (a) RC1, (b) RC2, (c) RC3 and (d) $\mathrm{RC} 4$

\subsubsection{Steel bracing}

A steel bracing system also has several advantages, which makes it another effective alternative to provide additional lateral stiffness and strength to the structure. Braced systems exhibit high lateral strength and stiffness under moderate to large earthquake conditions (Stefani and Scotta 2014). Steel bracings are easy to apply and they can be applied externally without disturbance to the building's occupants. The steel has a high strength-to-weight ratio, thus the additional mass added to the structure is less as compared to the introduction of a RC structural wall (Goel and Lee 1990). The steel braces are modelled as axial tension/compression struts. The main input data for the model is the yield tensile strength of the member and the effective slenderness ratio, which controls the value of the maximum compressive strength.

The design of the cross bracing is based on the standard steel code. The bilinear model with kinematic strain hardening is employed for defining the steel material with modulus of elasticity of steel $\left(E_{s}\right)=20 \times 10^{5} \mathrm{MPa}$ and yield strength $(f y)=420 \mathrm{MPa}$. The cross bracing was designed considering IS 800 (2007), IS 875 (2003) and IITK-GSDMA guidelines for seismic evaluation and strengthening of buildings (Rai 2005). The geometrical details of the principle bracing element have symmetrical I-sections with a bottom and top flange width of $50 \mathrm{~mm}$, web height of $65 \mathrm{~mm}$ and a web thickness of $3.7 \mathrm{~mm}$. The cross bracing is applied in such a way that their centre line passes through the centre of the beam-column joints and the bracing connection should be adequate against out-of-plane failure and brittle fracture. The locations of the steel cross bracing for all of the studied building structures are presented in Fig. 8.

\subsubsection{Reinforced concrete jacketing}

$\mathrm{RC}$ jacketing is effective in correcting specific deficiencies in strength and/or deformation capacity, in order to improve longitudinal reinforcement development or lap-splices, identified during the detailed evaluation. Experimental results indicated that jacketing was effective to 

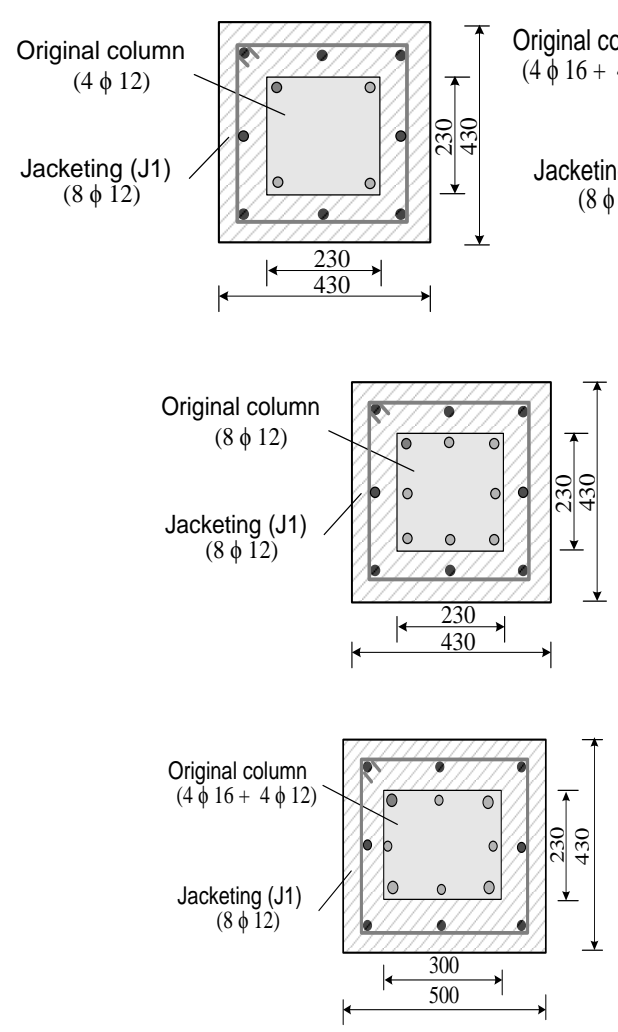

Original column
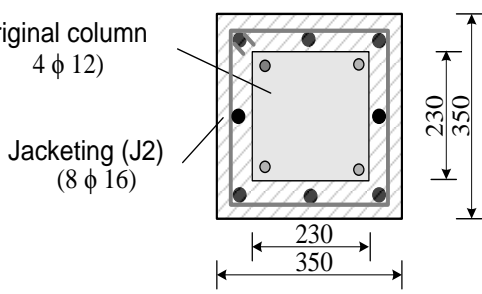

(a)

(b)
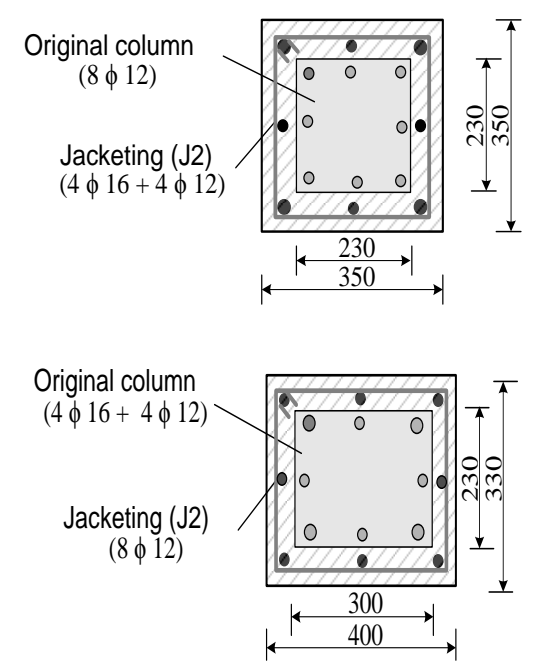

(c)

Fig. 9 Detailing of RC jacketing for building models: (a) RC1, (b) RC2, (c) RC3 and RC4

rehabilitate the existing structure, thus improving the strength, stiffness, and energy dissipation characteristics of existing structures (Alcocer 1992, Goel and Lee 1990). RC jacketing significantly improves the shear capacity, flexural strength, and ductility of damaged or weak members (Varum 2003). Column jacketing increases the overall building stiffness, but it is accompanied by an increase in the seismic forces induced in the building, which means that a change in the stiffness of the structure does not necessarily affect the drift values, but will also affect the displacements and the overall lateral forces (Rodrigues and Park 1991).

As presented the results in Table 3, all the studied buildings do not have the sufficient column beam capacity ratio. Thus, in this study jacketing is selected as one of the strengthening option for upgrading the seismic performance of Nepalese RC buildings. RC jacketing of columns on existing buildings is done on all four sides. The strength of new concrete material must be equal or greater than existing columns. The modelling of jacketing elements is done by considering the fact that the compressive strength of concrete is 5 MPa higher than in the existing columns (Rai 2005). For columns where extra longitudinal reinforcement is not required, a minimum of $12 \emptyset$ bars in the four corners and ties of $8 \emptyset @ 100 \mathrm{~mm} \mathrm{c} / \mathrm{c}$ should be provided with $135^{\circ}$ bends and $10 \mathrm{~mm} \emptyset \mathrm{leg}$ lengths. Results from the analysis show that the actual thickness of retrofitting in columns is smaller than the minimum value provided by the code. Therefore, in this study, two cases of RC jacketing are considered for seismic strengthening purposes. The first one is RC jacketing J1, 


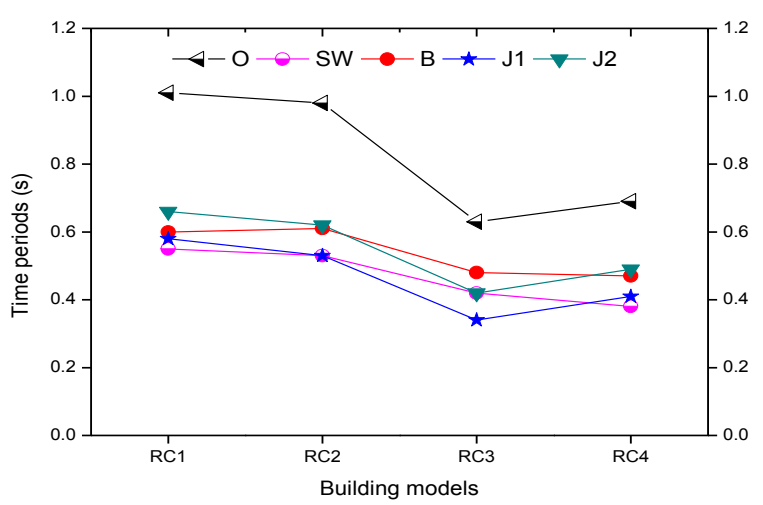

Fig. 10 First mode time periods of structures

Table 5 Time periods (s) of structures

\begin{tabular}{|c|c|c|c|c|c|c|}
\hline \multirow{3}{*}{ Model } & \multirow{3}{*}{ Mode type } & \multicolumn{5}{|c|}{ Time periods $(\mathrm{S}) /$ direction } \\
\hline & & \multicolumn{5}{|c|}{ Strengthening solutions } \\
\hline & & Original & Shear wall & Bracing & Jacketing 1 & Jacketing 2 \\
\hline \multirow{3}{*}{$\mathrm{RC} 1$} & $1 \mathrm{st}$ & $1.01(\mathrm{X})$ & $0.55(\mathrm{X})$ & $0.60(\mathrm{X})$ & $0.58(\mathrm{X})$ & $0.66(X)$ \\
\hline & 2nd & $0.87(\mathrm{Y})$ & $0.53(\mathrm{Y})$ & $0.57(\mathrm{Y})$ & $0.55(\mathrm{Y})$ & $0.62(\mathrm{Y})$ \\
\hline & $3 \mathrm{rd}$ & $0.38(\mathrm{X})$ & $0.30(\mathrm{X})$ & $0.38(\mathrm{X})$ & $0.35(\mathrm{X})$ & $0.37(\mathrm{X})$ \\
\hline \multirow{3}{*}{$\mathrm{RC} 2$} & $1 \mathrm{st}$ & $0.98(\mathrm{Y})$ & $0.53(\mathrm{Y})$ & $0.61(\mathrm{Y})$ & $0.53(\mathrm{Y})$ & $0.62(\mathrm{Y})$ \\
\hline & 2 nd & $0.95(\mathrm{X})$ & $0.50(\mathrm{X})$ & $0.55(\mathrm{X})$ & $0.50(\mathrm{X})$ & $0.58(\mathrm{X})$ \\
\hline & $3 \mathrm{rd}$ & $0.90(\Theta)$ & $0.29(\Theta)$ & $0.37(\Theta)$ & $0.47(\Theta)$ & $0.55(\Theta)$ \\
\hline \multirow{3}{*}{$\mathrm{RC} 3$} & $1 \mathrm{st}$ & $0.63(X)$ & $0.42(\mathrm{X})$ & $0.48(\mathrm{X})$ & $0.34(\mathrm{X})$ & $0.42(\mathrm{X})$ \\
\hline & 2 nd & $0.51(\mathrm{Y})$ & $0.38(\mathrm{Y})$ & $0.41(\mathrm{Y})$ & $0.30(\mathrm{Y})$ & $0.36(\mathrm{Y})$ \\
\hline & $3 \mathrm{rd}$ & $0.50(\Theta)$ & $0.23(\Theta)$ & $0.32(\Theta)$ & $0.28(\Theta)$ & $0.34(\Theta)$ \\
\hline \multirow{3}{*}{$\mathrm{RC} 4$} & $1 \mathrm{st}$ & $0.69(\mathrm{X})$ & $0.38(\mathrm{X})$ & $0.47(\mathrm{X})$ & $0.41(\mathrm{X})$ & $0.49(\mathrm{X})$ \\
\hline & $2 \mathrm{nd}$ & $0.56(\mathrm{Y})$ & $0.32(\mathrm{Y})$ & $0.40(\mathrm{Y})$ & $0.33(\mathrm{Y})$ & $0.40(\mathrm{Y})$ \\
\hline & $3 r d$ & $0.50(\Theta)$ & $0.23(\Theta)$ & $0.33(\Theta)$ & $0.30(\Theta)$ & $0.36(\Theta)$ \\
\hline
\end{tabular}

which is based on the minimum requirement on the code (i.e., code specifies the minimum thickness of jacket should be $100 \mathrm{~mm}$ ), where as the other jacketing, termed $\mathrm{J} 2$, consists of actual calculation from the standard procedures. All of the columns in the buildings are considered for the jacketing purpose. The final cross section and detailing of jacketing are summarised in Fig. 9.

\section{Efficiency of the retrofitting solutions: discussion of the numerical results}

\subsection{Time periods}

The elastic structural time periods from the eigen-value analysis in the first modes are presented in Fig. 10. In most of the cases, the engineered structures have lower time periods, both in original and retrofitted structures, than non-engineered ones. It is evident that the buildings 
associated with lower time periods have better performance as compared to the lower ones. The results also show that the reduction of the time periods of the structure is as a result of strengthening solutions. The structures strengthened with RC shear walls, steel bracing, and jacketing have lower, intermediate, and higher levels of time periods. In fact, the structures retrofitted with the RC shear walls attracts higher forces due to the increase in stiffness, which results in a reduction in the natural period of the structures. The time periods of the first three modes are tabulated in Table 5.

\subsection{Performance of retrofitted structures}

The seismic performance of structures with and without retrofitting measures is studied using an adaptive pushover analysis. The representative plotting of maximum shear resistance by different rehabilitation/strengthening solutions during the adaptive pushover analyses is plotted in Figs. 11-14. The comparative results of the initial stiffness and the maximum base shear ratio are plotted in Fig. 15. The figures show the effectiveness of each retrofitting scheme in different building structures. The results indicate that the use of RC shear walls has a maximum shear strength capacity in most of the buildings, while retrofitting the frame by steel cross bracing and reinforced concrete jacketing have an intermediate effect. The results from the analyses are summarised as follows:
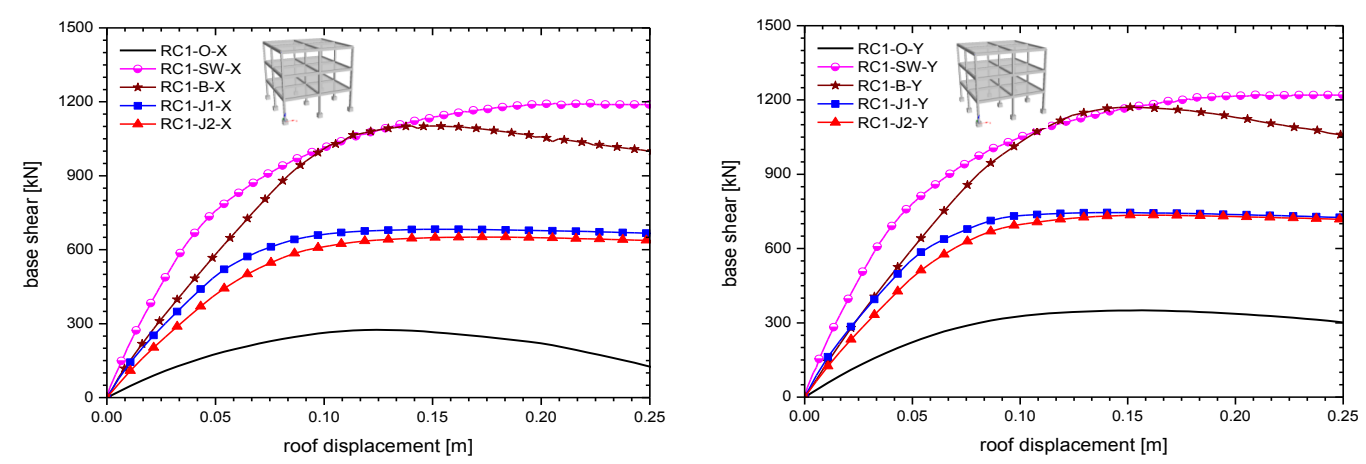

Fig. 11 Capacity curves of original and retrofitted building model RC1 loaded in $X$ and $Y$ directions respectively
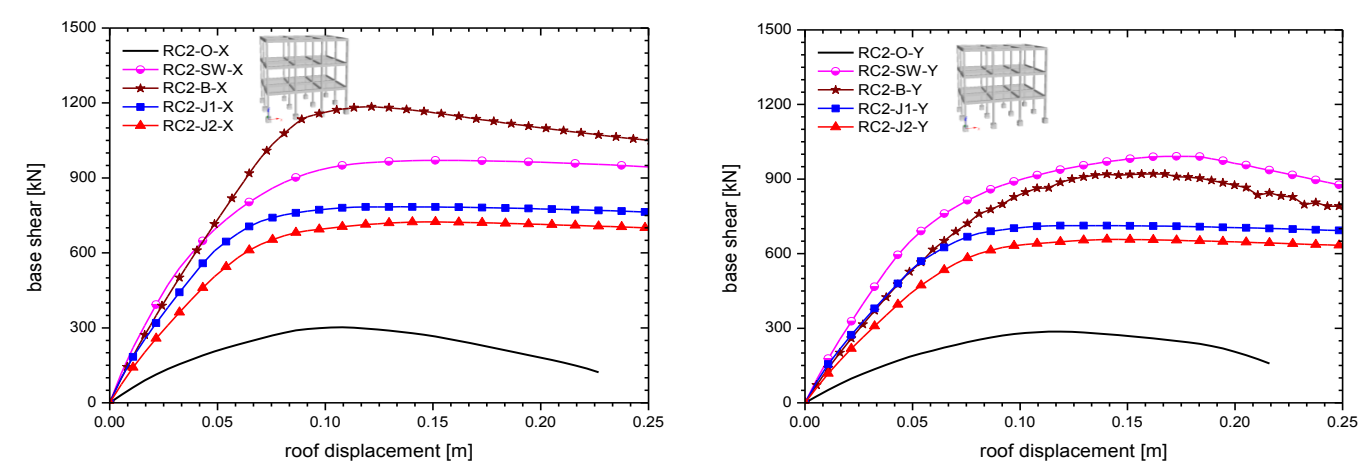

Fig. 12 Capacity curves of original and retrofitted building model RC2 loaded in $X$ and $Y$ directions respectively 

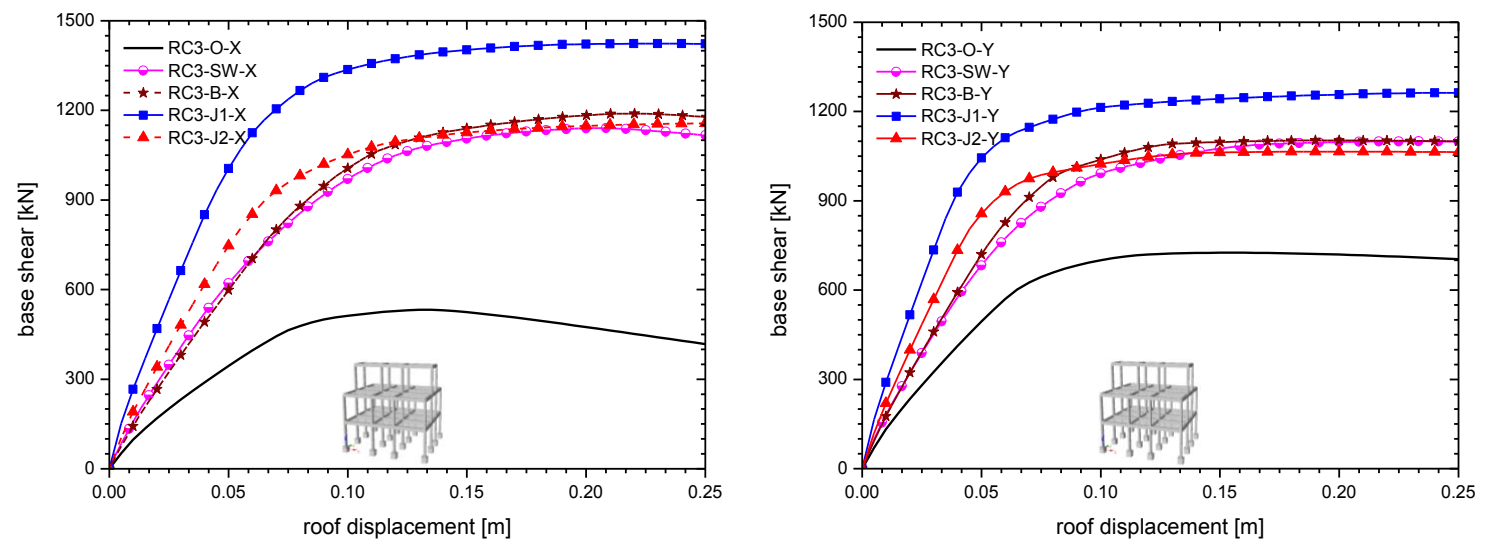

Fig. 13 Capacity curves of original and retrofitted building model RC3 loaded in $X$ and $Y$ directions respectively
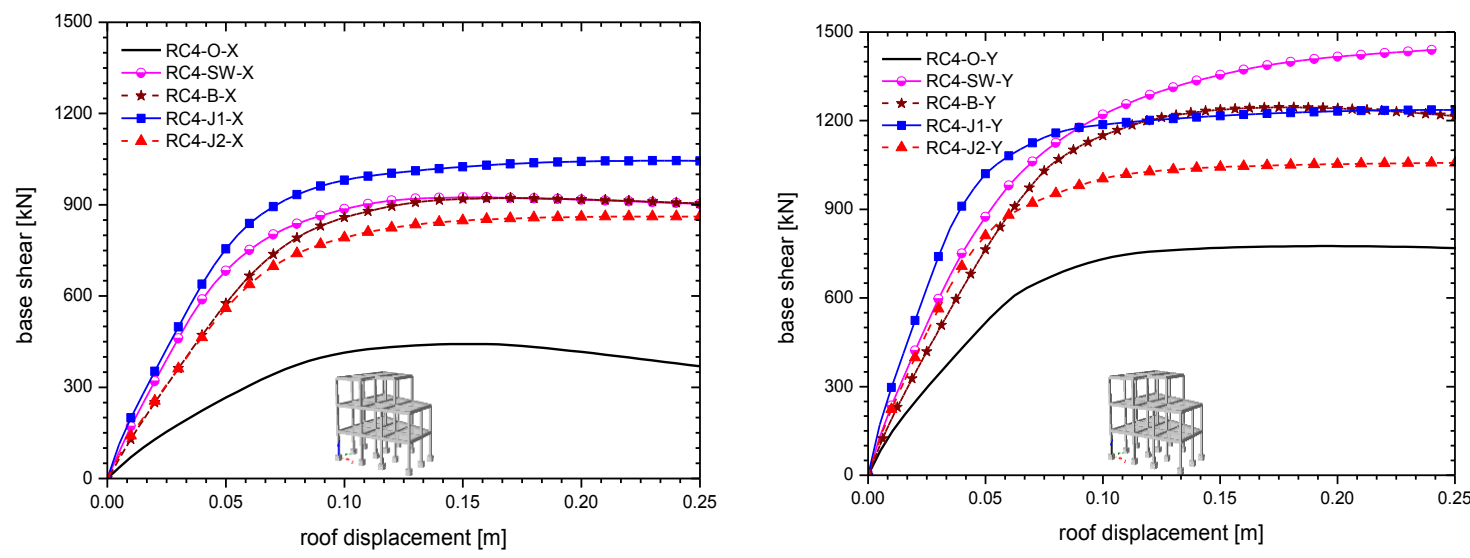

Fig. 14 Capacity curves of original and retrofitted building model RC4 loaded in $X$ and $Y$ directions respectively

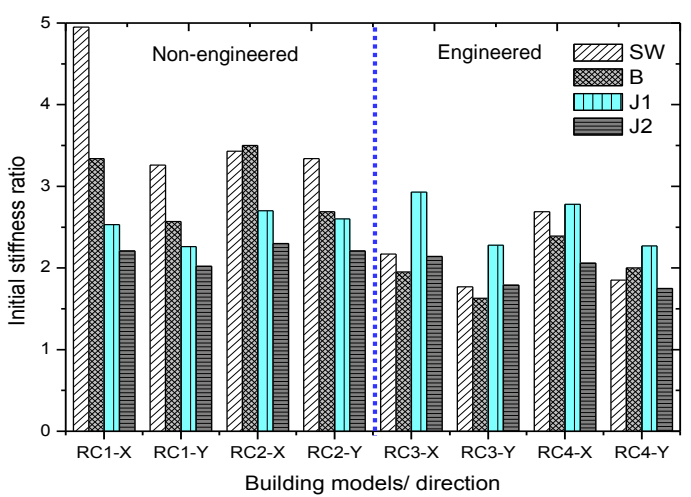

(a)

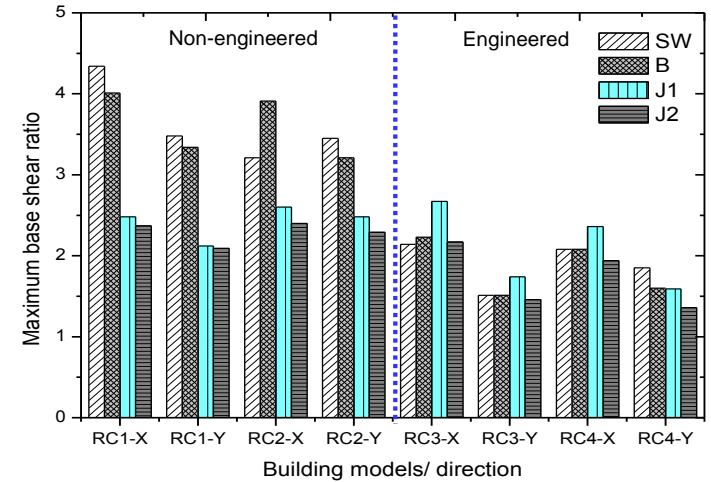

(b)

Fig. 15 Performance of structures in terms of: (a) initial stiffness ratio; and (b) maximum base shear ratio in $X$ and $Y$ directions respectively 
- As expected, the existing engineered buildings show improved strength and stiffness levels as compared to the non-engineered buildings. The strength and stiffness of both types of structure highly increase with different retrofitting solutions. In non-engineered structures the strength and initial stiffness increases in the range of (2.1-4.34) and (2.0-4.9) times, whereas, the values are limited to (1.36-2.67) and (1.6-2.9) times in engineered structures.

- Force displacement curves show that strengthening solutions greatly increase the lateral resistance and initial stiffness of the structures. Maximum base shear and initial stiffness of the existing structures with shear wall (SW), steel bracing (B), jacketing (J1) and jacketing (J2) increase in the range of (1.52-4.35), (1.52-4.01), (1.59-2.67) and (1.36-2.40), and (1.77-4.95), (1.63-3.50), (2.26-2.93) and (1.75-2.30) respectively.

- Non-engineered structures retrofitted with shear walls and bracing have higher maximum base shear and initial stiffness ratios as compared to the engineered structure. It indicates that shear walls and steel bracing are more effective in structurally deficient structures.

\subsection{Inter-storey drift}

In this section, the global behavior of the original and retrofitted structures is compared in terms of inter-storey drift. It is known that for each building, local behavior of each element should be verified to shake for particular local mechanism. However, the global drift parameters are used to fulfill the research need. The various international guidelines (Vision 2000 1995, FEMA 356 2000) also specify the allowable drifts for the design and assessment of structures that are expected to experience dynamic loads.

Figs. 16-19 show the inter-storey drift profile with different rehabilitation schemes. It shows that the jacketing has minimum effect for the resulting inter-storey drift, whereas rehabilitating the frames using RC shear walls or steel bracing have higher effects. This can be attributed to the fact that adding the RC shear wall or steel cross bracing increased the stiffness of the structure. It should be noted that for the aforementioned rehabilitation schemes, the failure occurred in the nonductile columns (in building models RC1 and RC2). As expected, engineered buildings have improved inter-storey drift for both original and retrofitted structures.

As observed in the figures, the rehabilitated buildings considerably reduced the storey drift among the different stories. Shear walls reduced the maximum drift value in all of the structures. Steel bracing and jacketing also resulted in the significant reduction of IS drift. It is worth noting that the rehabilitation scheme using steel $X$-bracing results in a significant increase of axial force on the existing columns in the lower stories. It indicates the importance of strengthening the existing columns to increase their axial capacity in order to be able to tolerate the axial force accompanied by the lateral loads due to the introduction of the steel braces. In such a situation, retrofitting the foundation might be needed. In any structure, if a large drift value is located on a certain storey, bracing might be concentrated for that storey in order to affect that specific drift value.

In Fig. 20, the RC shear wall reduces more than 50\% of the inter-storey drift compared to other retrofitting measures. In fact, the shear wall and $X$-bracing deformations are characterised by flexural beam behaviour. However, the deformations of the moment resisting frames are characterised by shear beam behaviour. Thus, the inter-storey drift associated with the rehabilitation scheme of the introduction of a $\mathrm{RC}$ wall or using steel $X$-bracing has the advantages of having lower inter-storey drift. 

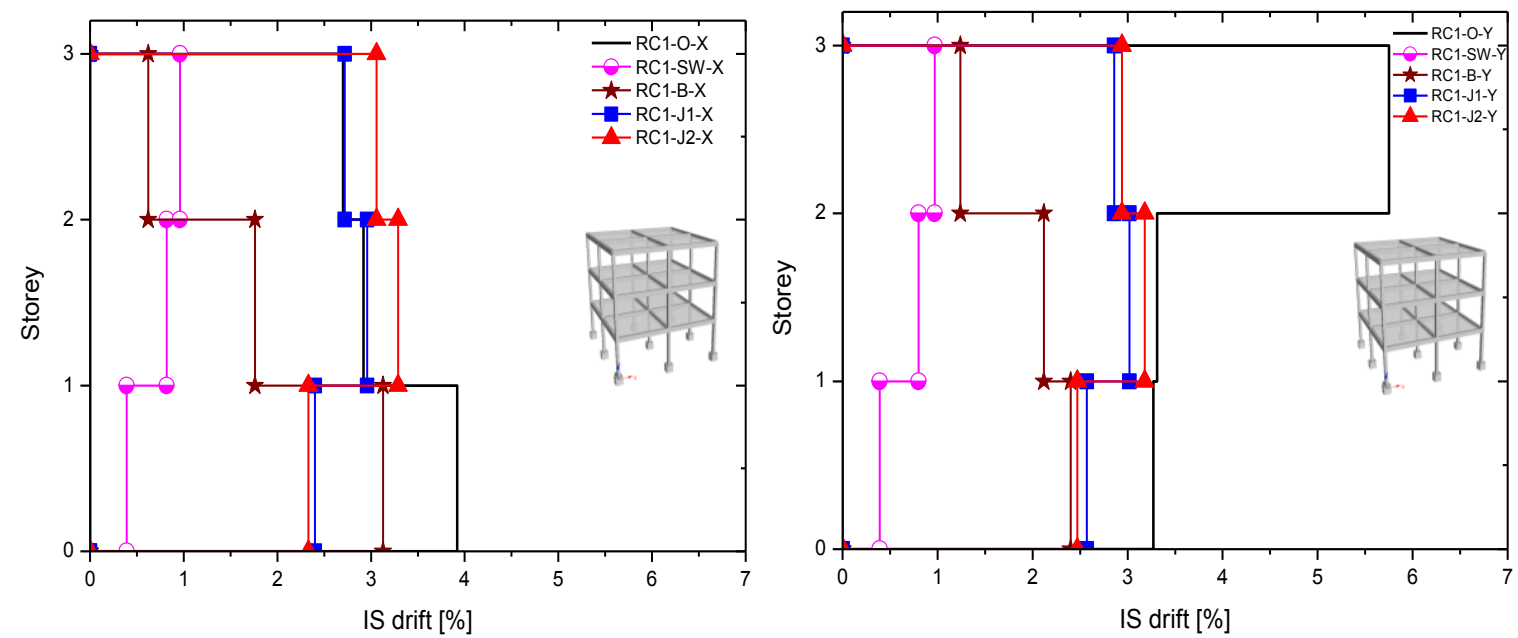

Fig. 16 IS drift of original and retrofitted building model RC1 loaded in $X$ and $Y$ directions respectively
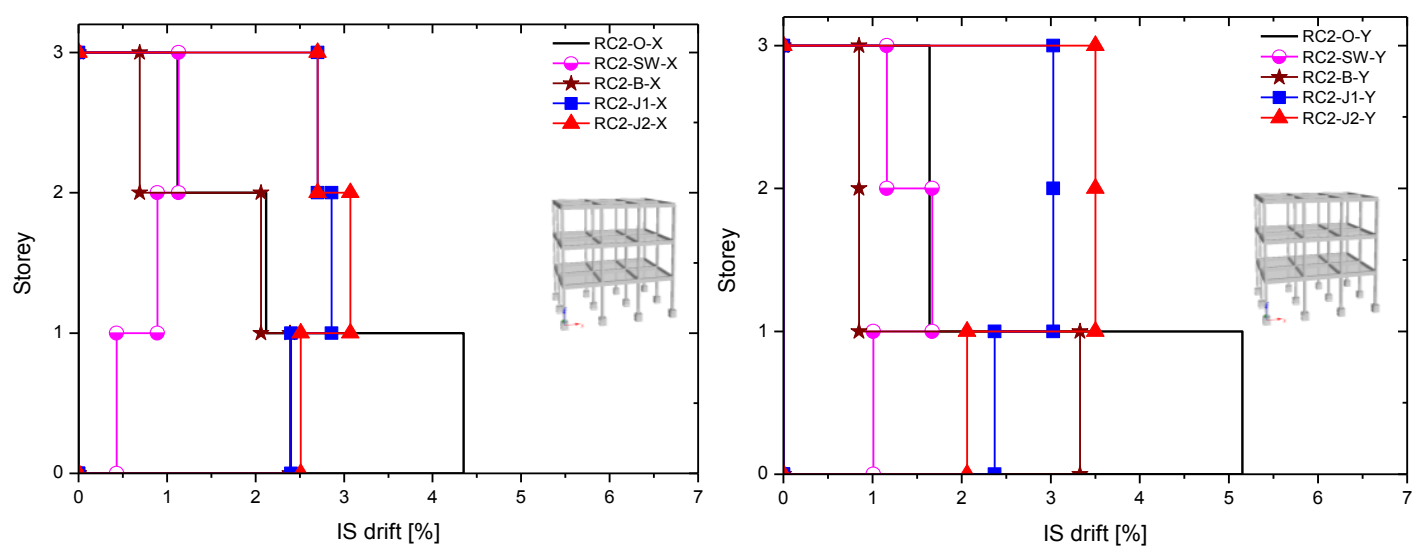

Fig. 17 IS drift of original and retrofitted building model RC2 loaded in $X$ and $Y$ directions respectively
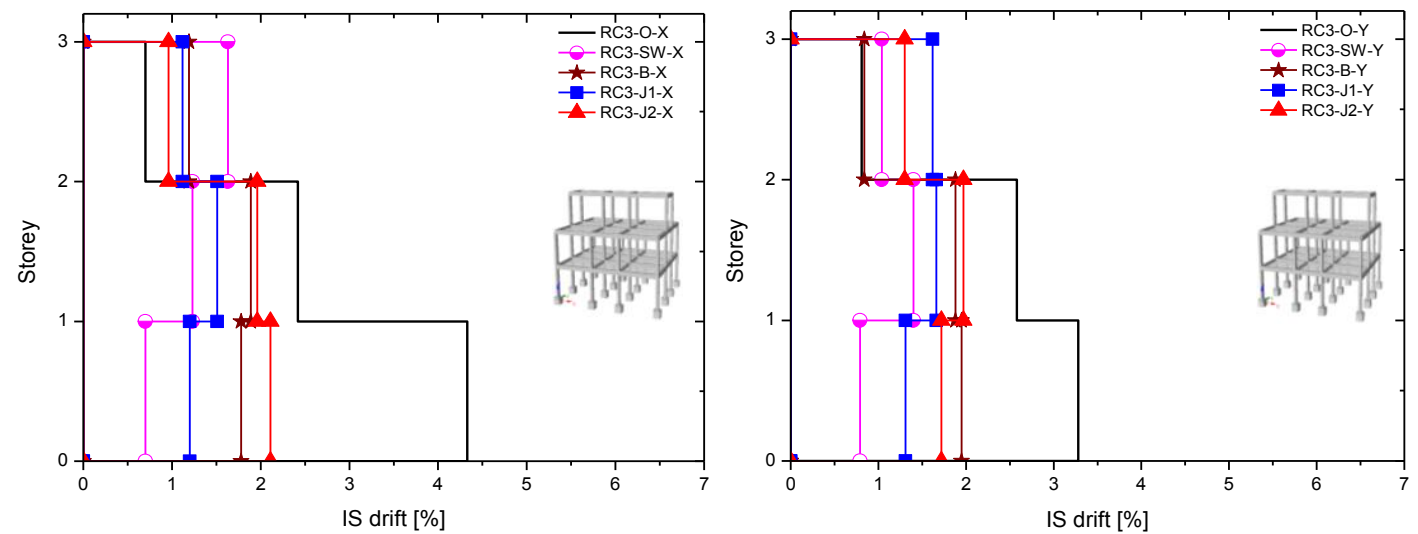

Fig. 18 IS drift of original and retrofitted building model RC3 loaded in $X$ and $Y$ directions respectively 

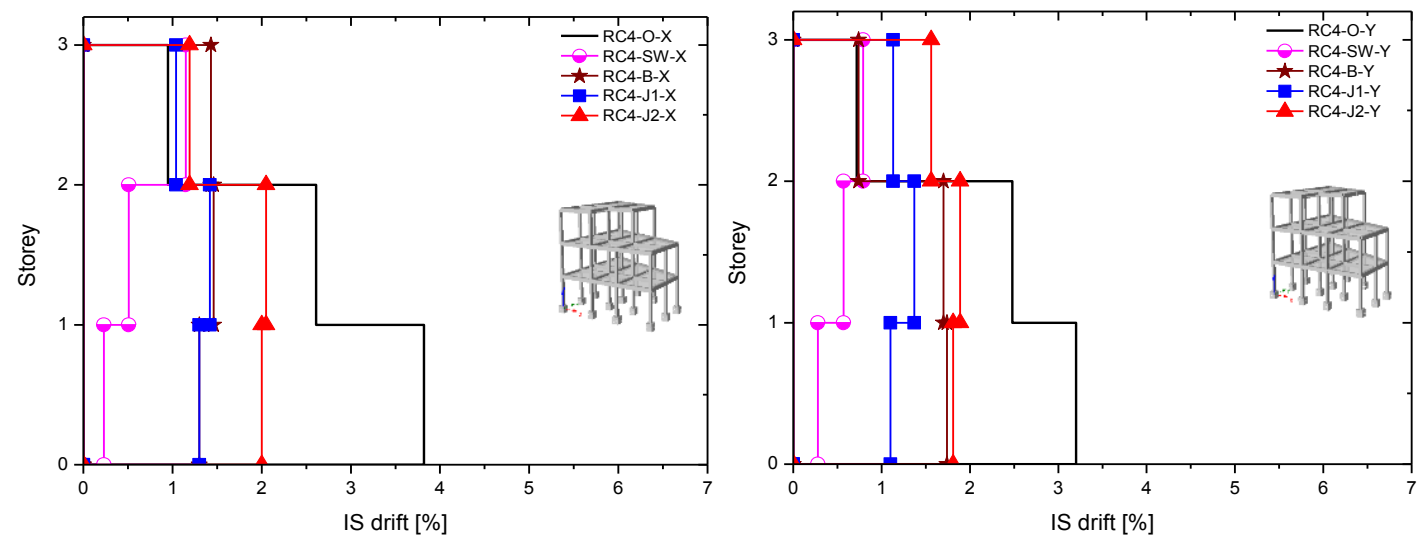

Fig. 19 IS drift of original and retrofitted building model RC4 loaded in $X$ and $Y$ directions respectively
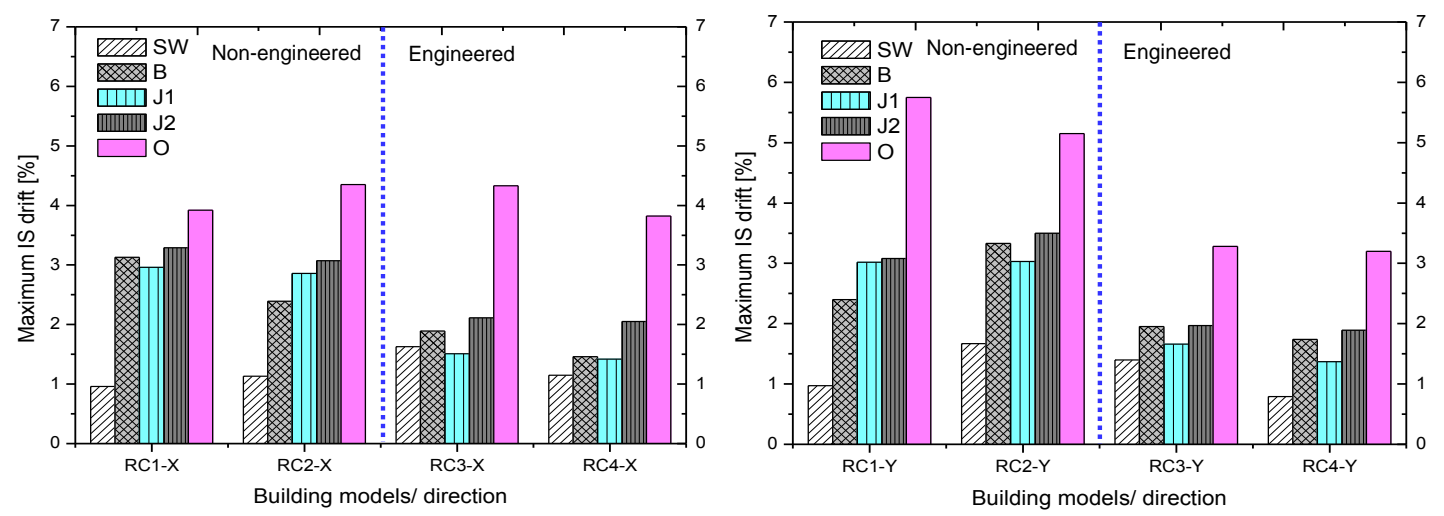

Fig. 20 Comparison of maximum IS drift with different retrofitting solutions

\subsection{Energy dissipation}

In this section, the total cumulative energy dissipation of the original and retrofitted structures is studied. In the proper seismic behaviour of a structure, the input energy to the structure due to the earthquake needs to be dissipated, depending on the expected performance of the structure. However, the area enclosed in the hysteretic loops of the original structure is smaller than that of the retrofitted one. The results from the numerical analyses show that strengthening of the RC frames with different retrofitting measures have good energy dissipation potential in addition to the increased stiffness and strength of the structures. Figs. 21-24 plot the evolution of the total cumulative energy dissipation (TCED) in the original and strengthened frames. The buildings retrofitted with RC shear wall or steel $X$-bracing dissipated higher amounts of energy than did the jacketing, which indicates that the introduction of a RC shear wall would be more efficient in resisting the lateral loads than would the use of jacketing, yet this solution would be impractical if the building was occupied during rehabilitation. In such a case, steel bracing could be an alternative. The total cumulative energy dissipation ratio of the longitudinal $(X)$ and transverse $(Y)$ directions of loadings is presented in Fig. 25. From the analyses of the energy dissipation results, the main conclusions are: 

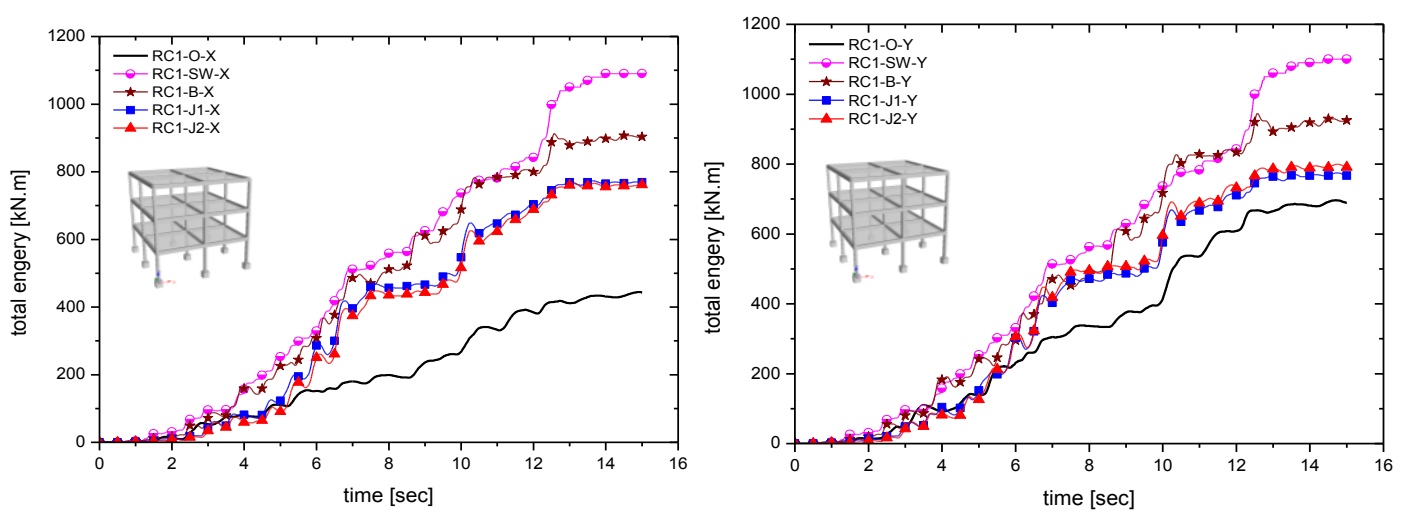

Fig. 21 Total energy dissipation profiles for original and retrofitted building model RC1 in $X$ and $Y$ directions respectively
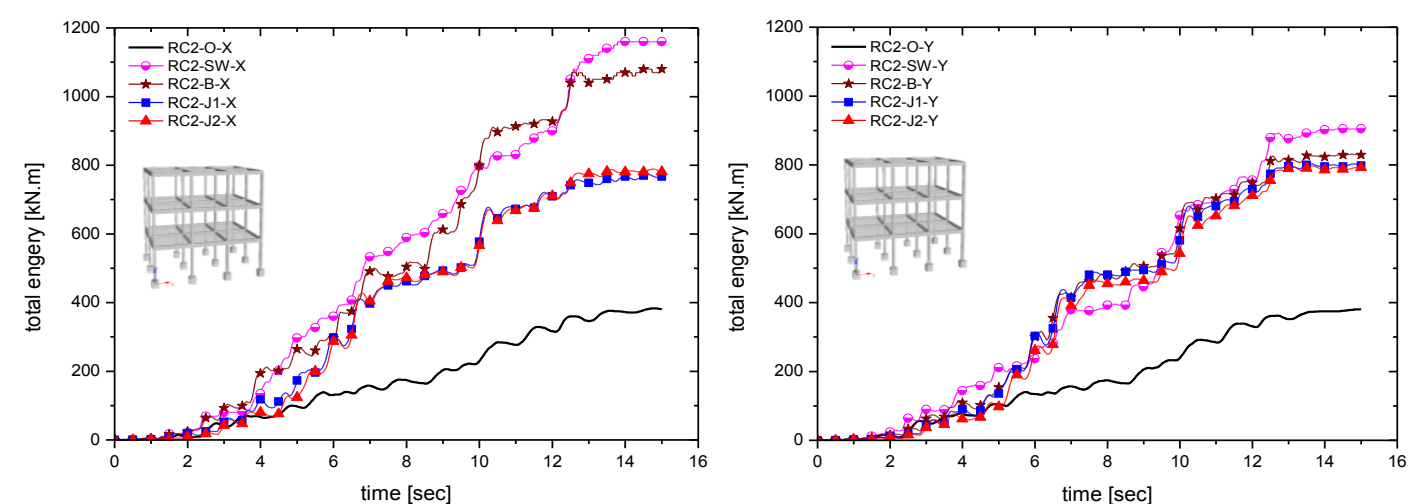

Fig. 22 Total energy dissipation profiles for original and retrofitted building model $\mathrm{RC} 2 \mathrm{X}$ and $Y$ directions respectively
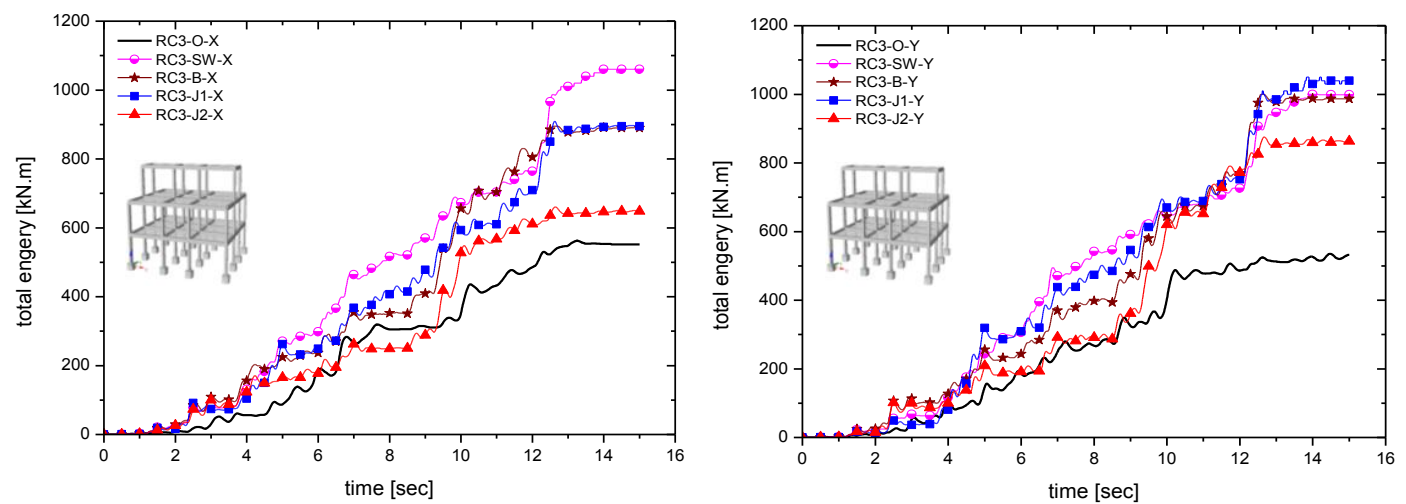

Fig. 23 Total energy dissipation profiles for original and retrofitted building model RC3 in $X$ and $Y$ directions respectively

- The better energy dissipation capacity is achieved through the three studied retrofitting solutions. Initially, the structures have low levels of energy dissipation capacity. After applying the 
proper retrofitting solutions, the total energy dissipation capacity of the structures increases up to three times over that of the existing one.

- The TCED ratio (energy dissipation of retrofitted structures/energy dissipation of original structures) for non-engineered building structures is in the range of (1.11-3.04). The value is limited to (0.93-1.96) in engineered buildings.

- There is a variation of energy dissipation patterns in different retrofitting solutions. The shear wall and bracing have improved energy dissipation capacity compared to jacketing.

- The different retrofitting methods work more effectively in non-engineered buildings. It is due to the fact that initially non-engineered structures have very weak RC elements (beam and column elements). After applying the retrofitting measures, global performance of structure is highly increased in these structures.

\subsection{Frame hysteretic curve}

In the previous sections, the global behaviour of the structures in terms of strength, stiffness, inter-storey drift, and energy dissipation capacity with and without retrofitting were studied. All of the applied retrofitting techniques highly enhanced the seismic performance of the structures. In
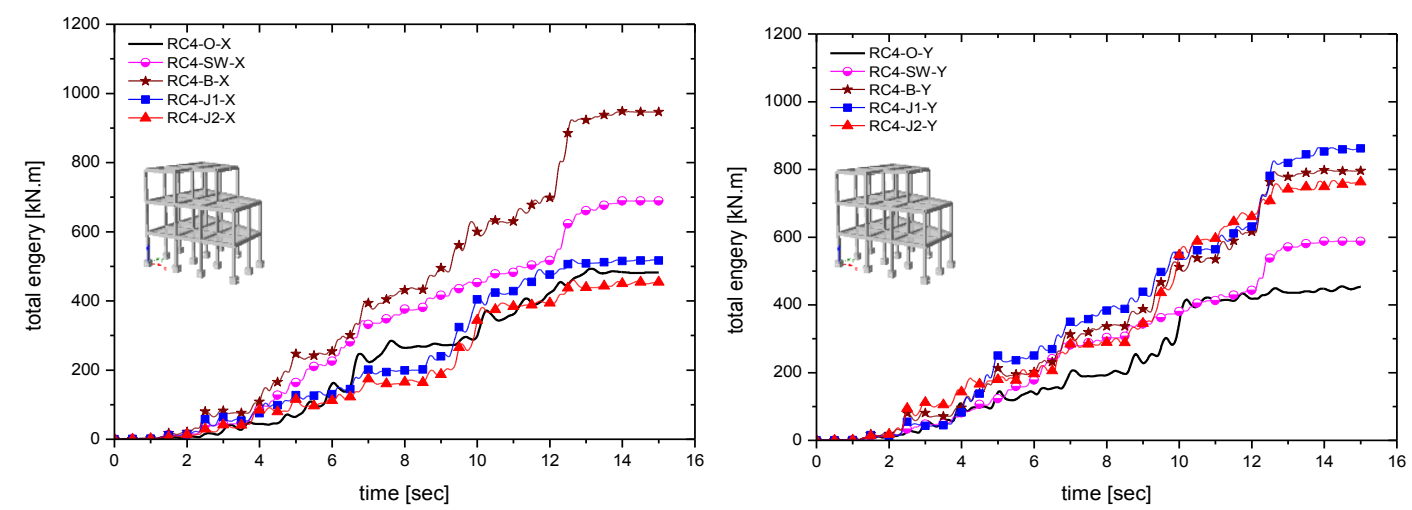

Fig. 24 Total energy dissipation profiles for original and retrofitted building model RC4 in $X$ and $Y$ directions respectively

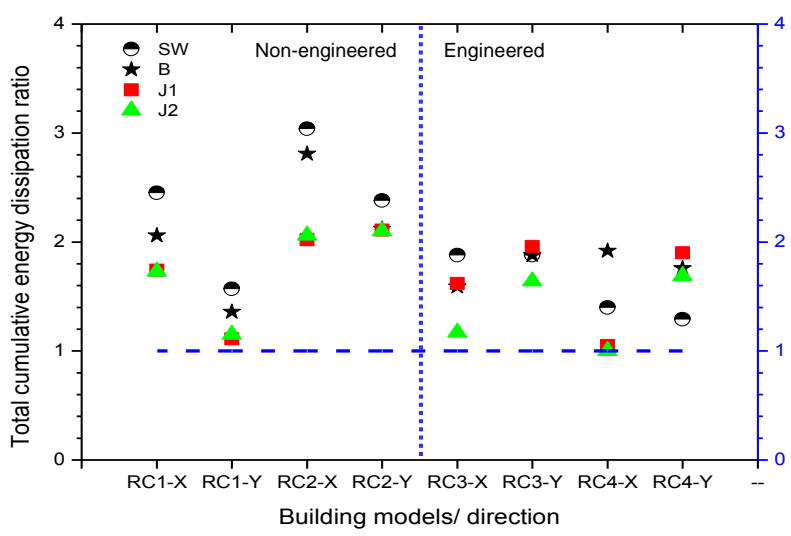

Fig. 25 Total cumulative energy dissipation ratio for longitudinal $(X)$ and transverse $(Y)$ direction of loadings 
this section, the seismic behaviour of column sections with the different retrofitting schemes is studied. The final results are presented in Figs. 26-28. In the figures, the RC jacketing of columns in different locations increases the deformation capacity to a certain extent. Besides, it is also confirmed that RC jacketing is a very effective strengthening technique, leading to values of resistance and stiffness of the strengthened column that are considerably higher than those of the original column.

Furthermore, a hysteretic curve shows that a column in non-engineered building models has a very high curvature demand and low moment carrying capacity. These column units reduce the energy dissipation capacity and significantly reduce the strength and stiffness of the structure. However, as expected, measured hysteretic loops for the jacketed columns indicated good energy dissipation, which increases strength, stiffness, and moment carrying capacity of the structures. Retrofitting the structures with shear walls and bracing are effective in reducing the moment demand ratio $\left((\mathrm{M})_{\text {Retrofitted }} /(\mathrm{M})_{\text {Original }}\right)$ of the columns. However, bracing has a higher curvature demand ratio $\left((1 / \rho)_{\text {Retrofitted }} /(1 / \rho)_{\text {Original }}\right)$ than does a shear wall. As expected, the hysteretic behaviour of engineered columns demonstrates the better performance in all of the analyses. The
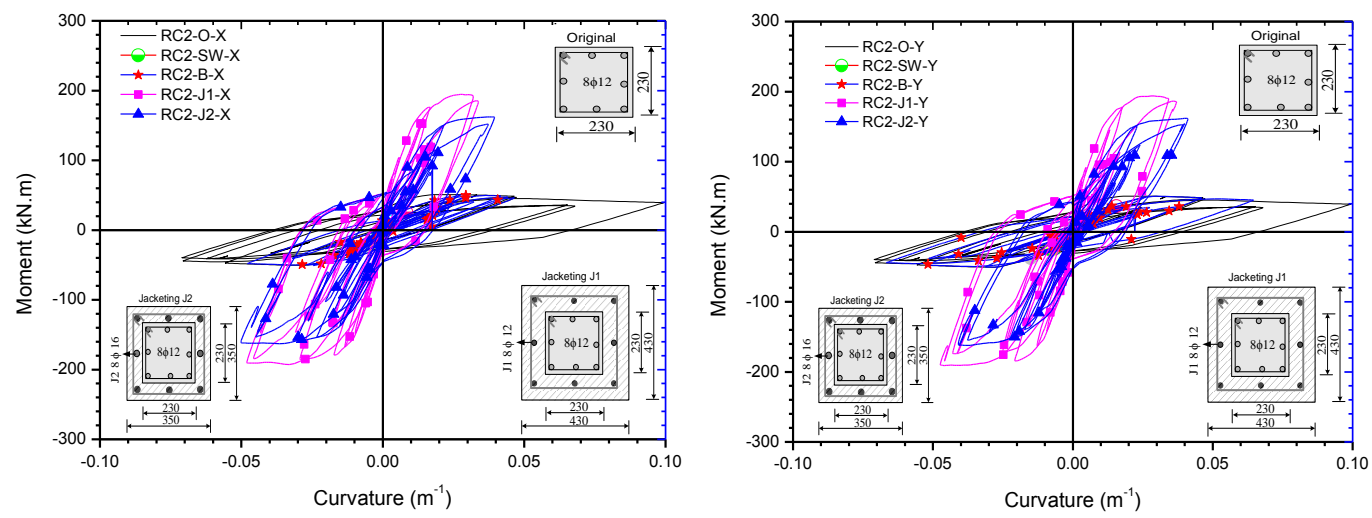

Fig. 26 Frame hysteretic curves for original and retrofitted interior column for $X$ and $Y$ directions respectively for building model RC2
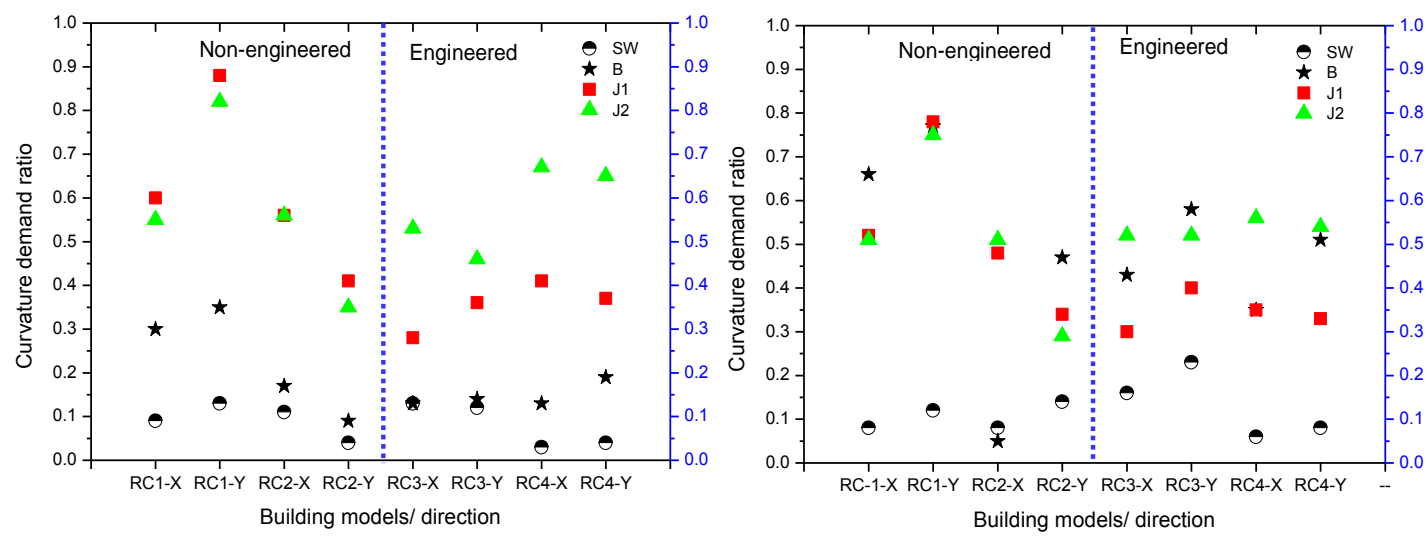

Fig. 27 Curvature demand ratio for corner and interior column for studied buildings in $X$ and $Y$ directions respectively 

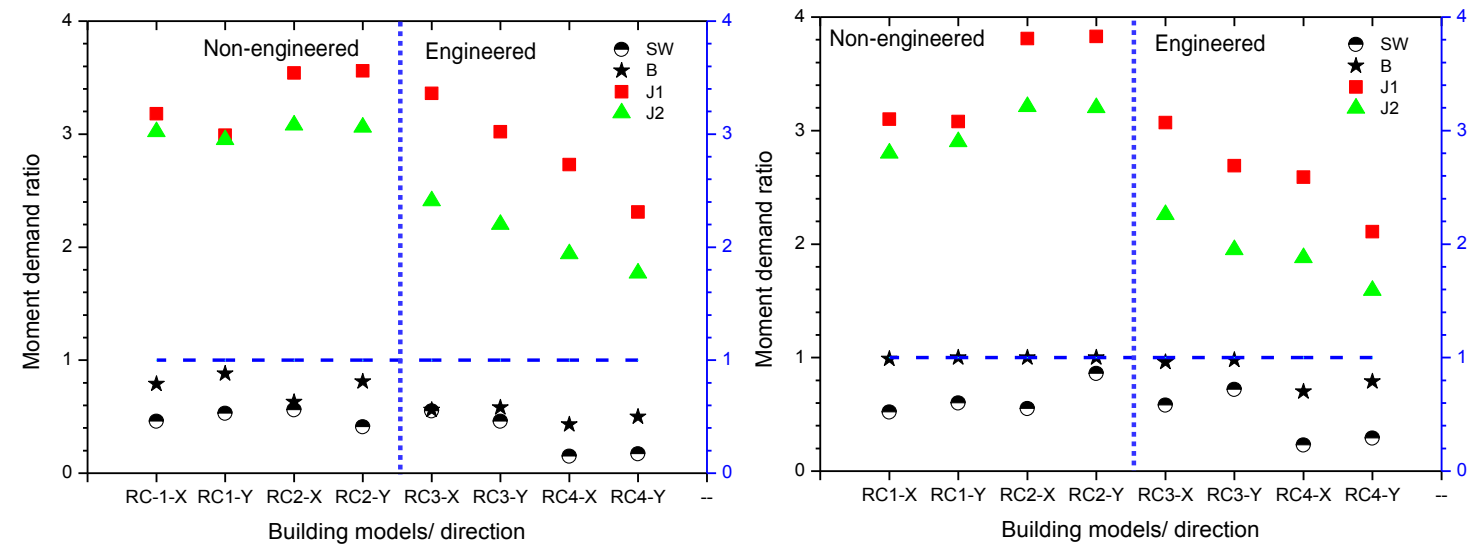

Fig. 28 Moment demand ratio for corner and interior column for studied buildings in $X$ and $Y$ directions respectively

figure also shows that jacketing $\mathrm{J} 1$ has slightly improved in the moment carrying capacity as well as the moment, and curvature demands of the engineered buildings. However, the effects are negligible in non-engineered structures.

\subsection{Limit states for RC building structures in Nepal}

The vulnerability condition of the structure is directly related to the acceptable performance level of the structure. Researchers have studied inter-storey drift as well as global drift to specify the damage state criteria of the structures. In ATC 40 (1996) and FEMA 356 (2000), four limit states are defined based on the global behavior (inter-storey drift) as well as element deformation (plastic hinge rotation). Rossetto and Elnashai (2003) used five limit states for derivation of vulnerability curves based on observational data, while Chryssanthopoulos et al. (2000) used only two limit states. Erberic (2008), Silva (2013) used four limit state global drift in their study. For this, four limit states are defined namely: slight damage (fully operational), moderate damage (operational), extensive damage (life safety) and collapse. The criteria were defined as:

- Slight damage: the global drift when $50 \%$ of the maximum base shear capacity is achieved;

- Moderate damage: global drift when $75 \%$ of the maximum base shear capacity is achieved;

- Extensive damage: global drift when the maximum base shear capacity is achieved;

- Collapse: global drift when the base shear capacity decreases by $20 \%$ or $75 \%$ of the ultimate global drift taken from the pushover curve, whichever is achieved first.

Each damage state criteria have the strength and limitations. Inter-storey drift tends to provide a better correlation with damage, but it is not easily assessed for each structure and thus often a fixed

Table 6 Storey drift limits according to the VISION 2000 (1995)

\begin{tabular}{ccccc}
\hline \hline & \multicolumn{3}{c}{ Performance level } & \\
\hline & $\begin{array}{c}\text { Fully } \\
\text { operational }\end{array}$ & Operational & $\begin{array}{c}\text { Life } \\
\text { safety }\end{array}$ & $\begin{array}{c}\text { Near } \\
\text { collapse }\end{array}$ \\
\hline Drift limit & $0.20 \%$ & $0.50 \%$ & $1.50 \%$ & $2.50 \%$ \\
\hline
\end{tabular}


Table 7 Storey drift limits according to FEMA 356 (2000)

\begin{tabular}{ccccc}
\hline \hline & \multicolumn{4}{c}{ Performance level } \\
\hline & $\begin{array}{c}\text { Immediate } \\
\text { Occupancy }\end{array}$ & $\begin{array}{c}\text { Damage } \\
\text { Control }\end{array}$ & $\begin{array}{c}\text { Life } \\
\text { safety }\end{array}$ & Structural stability \\
\hline Drift limit & $1 \%$ & $1-2 \%$ & $2 \%$ & $4 \%$ \\
\hline
\end{tabular}

Table 8 Drift limit (\%) associated with various damage levels (Ghobarah 2004)

\begin{tabular}{ccc}
\hline \hline State of damage & Ductile MRF & Non-ductile MRF \\
\hline $\begin{array}{c}\text { No damage } \\
\text { Repairable damage } \\
\text { (a) Light damage }\end{array}$ & $<0.2$ & $<0.1$ \\
(b) Moderate damage & 0.4 & 0.20 \\
Irreparable damage (>yield point) & $<1.0$ & $<0.5$ \\
Severe damage-life safe-partial & $>1.0$ & 0.8 \\
$\begin{array}{c}\text { collapse } \\
\text { Collapse }\end{array}$ & 1.8 & $>1.0$ \\
\hline
\end{tabular}

Table 9 Basic performance objectives for buildings according to FEMA-356

\begin{tabular}{ccccc}
\hline \hline & Fully operational & Operational & Life safety & Near collapse \\
\hline \multirow{2}{*}{$\begin{array}{c}\text { Earthquake } \\
\text { Design level }\end{array}$} & $\begin{array}{c}\text { Occasional (72-yrp) } \\
\text { Rare (475-yrp) }\end{array}$ & $\mathrm{X}$ & & \\
& Very rare (970-2000) yrp & & $\mathrm{X}$ & \\
& & & & $\mathrm{X}$ \\
\hline
\end{tabular}

set of limit state values are used, regardless of the structural properties (Silva 2013). On the contrary, the global drift for a limit state can be derived considering structural characteristics of each frame with a low computational effort. The global drift parameters could not represent the actual damage in the frames where soft-storey failure mechanism might develop or in vertically irregular structures in which a maximum lateral displacement might occurs at intermediate floors.

The selection of the appropriate drift associated with different levels of damage for the design is significant in terms of economy and safety of the structures. The identification of drift levels associated with different states of damage remains one of the unsolved issues in the development of performance objectives. However, it is accepted that drift levels associated with specific damage categories may vary considerably with the structural system and construction materials. For rigorous analysis, it is necessary to define limit states for each individual structure. However, more research is needed, particularly in the development of realistic and quantitative estimates of drift-damage relationships. It is due to the fact that performance levels are associated with earthquake hazard and design levels. In Tables 6-8, the drift limits for each structural performance level, according to Vision 2000 (1995), FEMA 356 (2000), Ghobarah (2004) proposals, are presented. VISION 2000 and FEMA 356 proposed drift limit considering the structures were ductile moment resisting frame (ductile MRF). On the contrary, based on experimental data, field observations and measurements and theoretical analyses, Ghobarah (2004) proposed limit states for ductile and non-ductile moment resisting frame. Due to the similarity in structural detailing and 
building classification, the seismic safety assessment is this study is based on the maximum drift limit proposed by Ghobarah (2004). The basic performance objective proposed by FEMA 356 is presented in Table 9.

\subsection{Seismic vulnerability assessment}

In order to assess the seismic vulnerability of the four buildings under study, the results of the non-linear dynamic analysis for each direction were compared in terms of the maximum drift demands and the basic performance objectives indicated in Tables 8 and 9 . The vulnerability curves of all the building models are based on the dynamic analysis with artificial ground motion records. Due to the lack of actual and sufficient time history data, scaling of existing artificial time history data was done for intermediate values. Figs. 29 to 32 present the seismic vulnerability curves of non-engineered and engineered buildings with the standard drift limit proposed by Ghobarah (2004).

Comparing the maximum inter-storey drift demands with the limit states, it was observed that non-engineered (RC1 and RC2 building models) have the higher drift demand. However, the

limiting drift for collapse is only $1 \%$ for non-engineered and $3 \%$ for engineered buildings. The results show that all the existing non-engineered buildings in Nepal exhibit high vulnerability
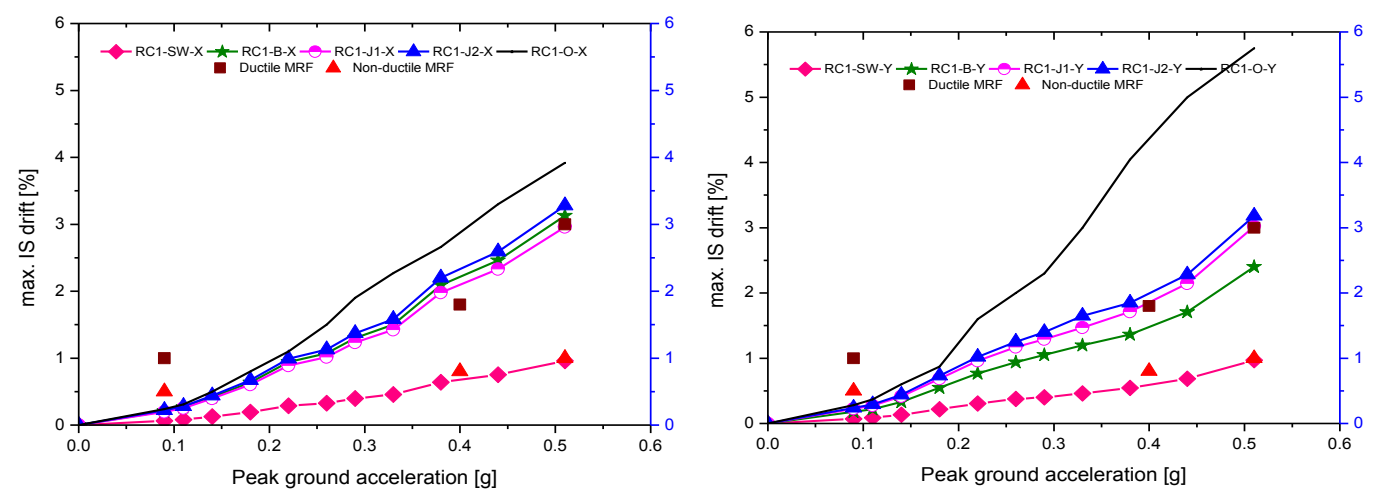

Fig. 29 Seismic vulnerability curves for RC1 building model loaded in the $X$ and $Y$ directions respectively
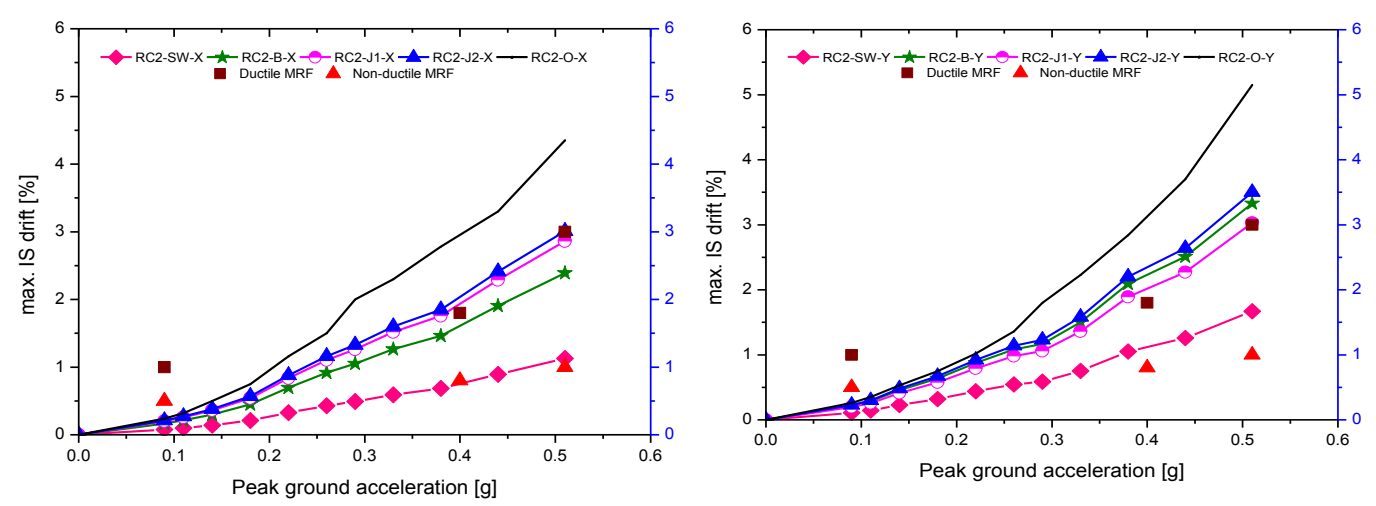

Fig. 30 Seismic vulnerability curves for building model RC2 loaded in the $X$ and $Y$ directions respectively 

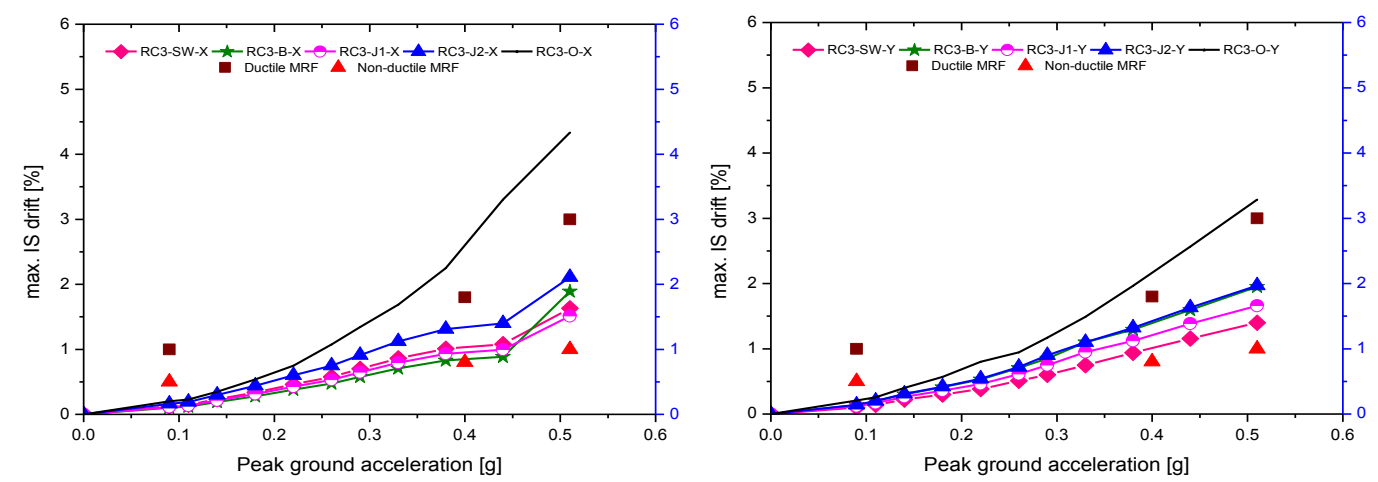

Fig. 31 Seismic vulnerability curves for building model RC3 loaded in the $X$ and $Y$ directions respectively
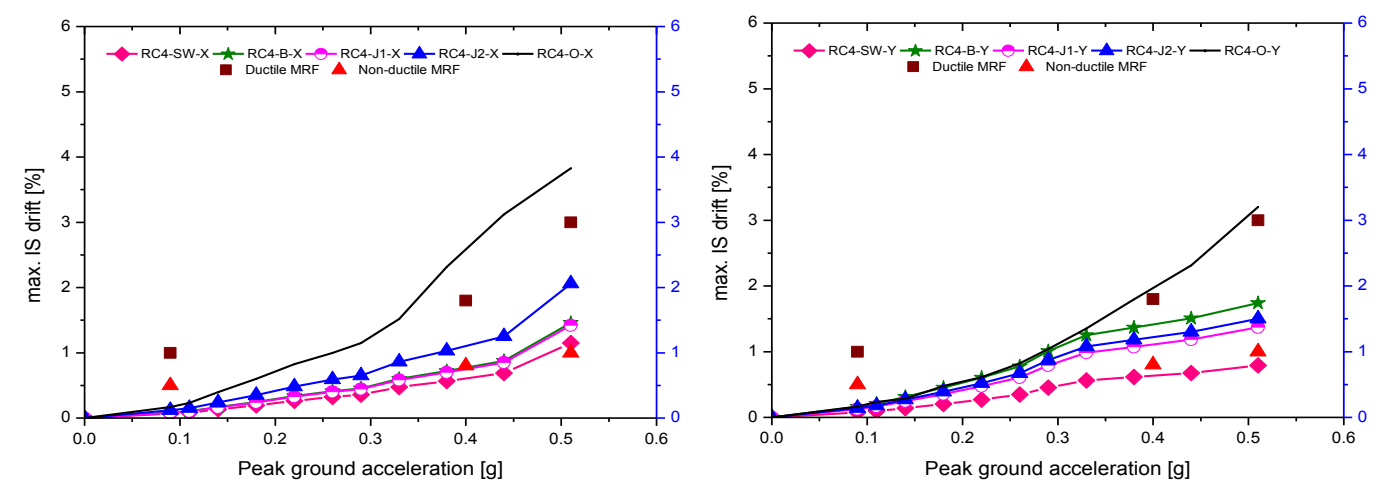

Fig. 32 Seismic vulnerability curves for building model RC4 loaded in the $X$ and $Y$ directions respectively

within the intermediate level of peak ground acceleration range (around 0.30 to $0.40 \mathrm{~g}$ ). It means these buildings have very low lateral resistance, stiffness, and limited ductility. The nonengineered buildings only satisfied the 'operational' performance level of design intensity. The engineered buildings on the other hand have the better performance level within medium to high peak ground acceleration values. However, these buildings also do not satisfy the limit state criteria for life safety performance level. These imply the entire studied buildings are unsafe for future earthquakes. Therefore, the same structures were redesigned and the seismic strengthening solutions were applied for each building model. In Figs. 29 to 32, it was seen the response of structures with the different retrofitting solutions such as shear wall, steel cross bracing and jacketing. It shows that shear wall is the most effective solutions for seismic strengthening in both types of structures. All the building models retrofitted by shear walls are safe for all the performance levels. The steel cross bracing and RC jacketing also significantly improves the seismic performance of both types of structures. However, only the engineered building meets the life safety and collapse prevention performance criteria. This implies that the applied retrofitting solutions can protect the non-engineered structures within the intermediate level of ground shaking. As expected, the vulnerability reduction for the limit states of fully operational and operational take place for low peak ground values, while for the limit states of life safety and near collapse they occur for the larger peak ground accelerations. Furthermore, when performing an 
analysis to determine the increase in PGA from the original structure to retrofitted one for the fixed level of vulnerability, it was seen that the strengthening solutions shift the vulnerability curves to upward such that, for a given vulnerability value shift has the similar proportion for all the limit states. Based on these results, it is possible to observe that the effectiveness of the retrofit solution provides a uniform protection throughout the several limit states.

\section{Conclusions}

The present study focuses on the seismic assessment and evaluates the efficiency of the proper retrofitting solution for typical RC buildings in Nepal. A finite element three-dimensional model is implemented to assess the non-linear response of the structures. From the results, we can say that adding a new shear wall, steel cross bracing, and RC jacketing to the existing structures as strengthening solutions increases its strength, stiffness and the energy absorption capacity. For increasing the efficiency of the retrofitting methods in RC moment resisting frames, special attention should be paid to the location of retrofitting measures. The main conclusions from the analyses are summarised as:

- The pushover curves for the non-engineered buildings in Nepal exhibit significant softening in lateral-load-capacity at larger level of roof displacement.

- The columns of non-engineered construction have lower displacement, ductility capacity, resulting in reduced energy dissipation capacity.

- All of the selected retrofitting solutions considerably reduce the first mode period of the structures. The buildings retrofitted with the RC shear walls attract higher forces due to the increase in stiffness, which results in a higher reduction in the natural period of the structures.

- RC jacketing of columns increases significant deformation capacity. It confirms that RC jacketing is a very effective strengthening technique, leading to uniformly distributed values of strength and stiffness of the strengthened column that are considerably higher than those of the original column. The measured hysteretic loops for the jacketed columns indicated good energy dissipation.

- In all aspects, RC jacketing $\mathrm{J} 1$ performs better than does jacketing $\mathrm{J} 2$ in all of the engineered buildings. However, both jacketing methods enhanced the structural performance in nonengineered buildings at nearly the same level. It indicates that small variations in the thickness of the RC jacketing do not have strong influence on structural behaviour of non-engineered structures.

- Result indicates that strengthening solutions highly increase the strength and stiffness of structures. The maximum base shear and initial stiffness of the structures with shear wall (SW), steel $X$-bracing (B), jacketing (J1) and jacketing (J2) increases in the range of (1.52-4.35), (1.52$4.01),(1.59-2.67)$ and $(1.36-2.40)$, and (1.77-4.95), (1.63-3.50), (2.26-2.93) and (1.75-2.30) respectively.

- The retrofitting measures considerably reduce the inter-storey drift. The shear walls reduce the maximum drift values in all of the structures. In most cases, the strengthening solutions reduce the drift value more than 50\%. For example, the final drift value, as a result of SW, B, J1 and J2, decreased from 4.50 to $1.75,2.30,2.20$ and 2.60 respectively.

- Strengthening solutions increased the energy dissipation potential in addition to the increasing stiffness and strength. The total energy dissipation capacity of all of the structures considerably increases with all of the applied retrofitting methods. The TCED ratio for non-engineered building 
structure is in the range of 1.11-3.04, whereas the value is limited to $0.93-1.96$ in engineered buildings.

- The column hysteretic curve demonstrated that most of the existing columns have very high curvature and low moment carrying capacity. The results also indicated that these column units have reduced energy dissipation capacity and significant reduction of the strength of the structure. However, measured hysteretic loops for the jacketed columns indicated good energy dissipation, which clearly reflects the moment and curvature demand of the column. Furthermore, in all buildings, shear wall and steel $X$-bracing were effective in reducing the moment demand ratio.

- In bracing schemes, the main effect is on the lower stories. In contrast, the effect of the jacketing appears in the whole structure. The results show that in any structure, if a large drift value is located in a certain storey, bracing might be concentrated for that storey in order to affect that specific drift value (mostly in non-engineered buildings).

- The existing non-engineered buildings in Nepal exhibit high vulnerability. The shear walls and $X$ bracing work better in non-engineered structures as compared to other retrofitting solutions.

- The seismic vulnerability curves of the engineered buildings indicate that all of the applied retrofitting solutions have better performance in all of the studied engineered buildings.

\section{Acknowledgements}

This research investigation is supported by the Eurasian University Network for International Cooperation in Earthquake (EU-NICE) through a fellowship for the Ph.D. research of the first author. This support is gratefully acknowledged.

\section{References}

Alcocer, S.M. (1992), "Rehabilitation of RC frame connections using jacketing", Tenth World Conference, Earthq. Eng., 9, 5235-5240.

ASCE (2003), Seismic evaluation of existing buildings, American Society of Civil Engineers, USA.

ATC-21 (1988), Rapid visual screening of buildings for potential seismic hazards, Applied Technology Council, California, US.

ATC-40 (1996), Seismic evaluation and retrofit of concrete buildings, Applied Technical Council, California Seismic Safety Commission, Redwood City, California, US.

BIA (1996), "The assessment and improvement of the structural performance of earthquake risk buildingsDraft for general release", NZ. Natl. Soc. Earthq. Eng., New Zealand.

Bothara, J. and Hiçyllmaz, K. (2008), "General observations of building behaviour during the $8^{\text {th }}$ October 2005 Pakistan earthquake”, Bul. NZ. Soc. Earthq. Eng., 41(4), 209-233.

Calvi, G.M. (2013), "Choices and criteria for seismic strengthening”, J. Earthq. Eng., 17(6), 769-802.

CEN (2004), Design of structures for earthquake resistance; Part 1: General Rules, seismic actions and rules for buildings, CEN, Brussels.

Chaulagain, H., Rodrigues, H., Jara, J., Spacone, E. and Varum, H. (2013), "Seismic response of current RC buildings in Nepal: A comparative analysis of different design/ construction", Eng. Struct., 49, 284-294.

Chaulagain, H., Rodrigues, H., Spacone, E. and Varum, H. (2014), "Study on design procedures of reinforced concrete buildings in Nepal and its impact on seismic safety", Advances in Struct. Eng. (in Press)

Chryssanthopoulos, M.K., Dymiotis, C. and Kappos, A.J. (2000), "Probabilistic evaluation of behaviour factors in EC8-designed R/C frames", Eng. Struct., 22(8), 1028-41. 
Disarno, L. and Manfredi, G. (2010), "Seismic retrofitting with buckling restrained braces: Application to an existing non-ductile RC framed building”, Soil Dyn. Earthq. Eng., 30, 1279-1297.

Elnashai, A.S. and Elghazouli, A.Y. (1993), "Performance of composite steel/concrete members under earthquake loading, Part I: Analytical model”, Earthq. Eng. Struct. Dyn., 22, 315-345.

Erberic, M.A. (2008), "Fragility based assessment of typical mid-rise and low-rise RC buildings in Turkey", Eng. Struct., 30(5), 1360-1374.

Erdik, M. and Durukal, E. (2008), "Earthquake risk and its mitigation in Istanbul”, Nat. Hazard., 44,181197.

FEMA-310 (1998), Handbook for the Seismic Evaluation of Buildings - A Prestandard, Federal Emergency Management Agency, Washington D.C., US.

FEMA356 (2000), Pre-standard and commentary for the seismic rehabilitation of buildings, Washington, DC: Federal Emergency Management Agency.

Fardis, M., Papailia, A. and Tsionis, G. (2012), "Seismic fragility of RC framed and wall-frame buildings designed to the EN-Eurocodes", Bul. Earthq. Eng., 10, 1767-1793.

Fradis, M., Schetakis, A. and Strepelias, E. (2013), "RC buildings retrofitted by converting frame bays into RC walls", Bul. Earthq. Eng., 11, 1541-1561.

Filippou, F.C., Bertero, E.P. and Popov, E.P. (1983), Effects of bound deterioration on hysteretic behavior of reinforced concrete joints, University of California, Berkeley, US.

Galal, K. and Sokkary, H. (2009), "Analytical investigation of the seismic performance of RC frames rehabilitated using different rehabilitation techniques", Eng. Struct., 31, 1955-1966.

Ghobarah, A. (2004), "On drift limits associated with different damage levels", Proceedings of the International Workshop Bled, 28, 321-332.

Goel, S.C. and Lee, H. (1990), "Seismic strengthening of RC structures by ductile steel bracing system", Fourth U.S. National Conference on Earthquake Engineering, Palm Springs, California, US.

IS 1893 (Part1) (2002), Indian Standard Criteria for Earthquake Resistant Design of Structures, Bureau of Indian Standards, Eds. Manak Bhavan and Bahadur Shah Zafar Marg, New Delhi.

IS 13920 (1993), Indian Standard Ductile Detailing of Reinforced Concrete Structures subjected to Seismic Force, Bureau of Indian Standards, Eds. Manak Bhavan and Bahadur Shah Zafar Marg, New Delhi.

IS 875 (2003), Code of Practice for design loads for buildings and structures, Bureau of Indian Standards, Eds. Manak Bhavan and Bahadur Shah Zafar Marg, New Delhi.

IS 800 (2007), General construction in steel, Bureau of Indian Standards, Eds. Manak Bhavan and Bahadur Shah Zafar Marg, New Delhi.

JICA (2002), The Study on Earthquake Disaster Mitigation in the Kathmandu Valley Kingdom of Nepal, Japan International Cooperation Agency (JICA) and Ministry of Home Affairs, His Majesty's Government of Nepal.

Kaplan, H., Yilmaz, S., Cetinkaya, N. and Atimtay, E. (2011), "Seismic strengthening of RC structures with exterior shear walls", Sadhana. Acad Proc. Eng. Sceince, 36, 17-34.

Madas, P. and Elnashai, A.S. (1992), "A new passive confinement model for the analysis of concrete structures subjected to cyclic and transient dynamic loading”, Earthq. Eng. Struct. Dyn., 21, 409-431.

Mander, J.B., Priestley, M.J.N. and Park, R. (1988), "Theoretical stress-strain model for confined concrete", J. Struct. Eng., 114(8), 1804-1826.

Martinez-Rueda, J.E. (1997), "Energy dissipation devices for seismic upgrading of RC structures", Ph.D. Thesis, Imperial College, University of London, London, UK.

Menegotto, M. and Pinto, P.E. (1973), "Method of analysis for cyclically loaded R.C. plane frames including changes in geometry and non-elastic behaviour of elements under combined normal force and bending", Symposium on the Resistance and Ultimate Deformability of Structures Acted on by Well Defined Repeated Loads, International Association for Bridge and Structural Engineering, Zurich, Switzerland.

Moehle, J.P. (2000), "State of research on seismic retrofit of concrete building structures in the US", Proceedings of US-Japan symposium and workshop on seismic retrofit of concrete structures-state of research and practice. 
NSET (2009), Seismic vulnerability evaluation guidelines for private and public buildings- Part I: Pre disaster vulnerability assessment, Government of Nepal, Ministry of Physical Planning and Works.

Pandey, M.R. and Molnar, P. (1988), "The distrubition of intensity of the Bihar-Nepal earthquake 15 January 1934 and bounds of the extent of the rupture zone", J. Nepal Geo. Soc., 5, 22-44.

Parajuli, H.R. (2009), "Dynamic analyses of low strength masonry houses based on site specific earthquake ground motions", Ph.D. Thesis, Department of Urban Management, Graduate School of Engineering, Kyoto University, Japan.

Rai, D. (2005), "Seismic evaluation and strengthening of existing buildings", Draft Final Report: AEarthuake Codes, IITK-GSDMA Project on Building Codes, Indian Institute of Technology Kanpur, Kanpur, India.

Rana, B.J.B. (1935), Nepal ko Maha Bhukampa (Great earthquake of Nepal), Jorganesh press, Kathmandu.

Rodrigues, H., Arêde, A., Varum, H. and Costa, A.G. (2012), "Experimental evaluation of rectangular reinforced concrete column behaviour under biaxial cyclic loading", Earthq. Eng. Struct. Dyn., 42(2), 239-259.

Rodrigues, M. and Park, R. (1991), "Repair and strengthening of reinforced concrete buildings for seismic resistance", Earthq. Spectra, 7(3), 439-459.

Rodrigues, H., Varum, H., Arêde, A. and Costa, A. (2011), "Comparison of different modelling strategies for the representation of non linear response of RC columns subjected to biaxial loading", International Conference on Recent Advances in Nonlinear Models, Struct. Conc. Appl., CORAN 2011, Eds. H. Barros, R. Faria, C. Pina and C. Ferreira, Coimbra, Portugal.

Rossetto, T. and Elnashai, A. (2003), "Derivation of vulnerability functions for European-type RC structures based on observational data", Eng. Struct., 25(10), 124-163.

SEAOC (1995), Vision 2000, Performance based seismic engineering of buildings, Vol. I and II: Conceptual framework, Sacramento (CA): Structural Engineers Association of California.

Seismo Soft (2006), A Computer Program for Static and Dynamic Nonlinear Analysis of Framed Structure, URL: http//www.seismosoft.com.

SERC (2002), Formulation of Guidelines for Assessment of Strength and Performance of Existing Buildings and Recommendations on Retrofitting Schemes to Ensure Resistance to Earthquakes, Structural Engineering Research Centre, September 2002, Chennai.

Silva, V. (2013), "Development of open models and tools for seismic risk assessment: application to Portugal", Ph.D. Thesis, University of Aveiro, Portugal.

Smyrou, E., Blandon, C., Antoniou, S., Pinho, R. and Crisafulli, F. (2011), "Implementation and verification of a masonry panel model for nonlinear dynamic analysis of infilled RC frames", Bul. Earthq. Eng., 9(6), 1519-34.

Stefani, L. and Scotta, R. (2014), "Optimal design of seismic retrofitting of RC frames with eccentric steel bracing", Bul. Earthq. Eng., 1-21.

Thermou, G.E., Pantazopoulou, S.J. and Elnashai, A.S. (2007), "Design methodology for seismic upgrading of substandard reinforced concrete structures", J. Earthq. Eng., 11(4), 582-606.

Varum, H. (2003), "Seismic assessment, strengthening and repair of existing buildings", Ph.D. Thesis, Department of Civil Engineering, University of Aveiro, Portugal.

Varum, H., Chaulagain, H., Rodrigues, H. and Spacone, E. (2013a), "Seismic assessment and retrofitting of existing RC buildings in Kathmandu", CINPAR 2013, 9th International Congress on Pathology and Repair of Structures, João Pessoa, Brazil.

Varum, H., Teixeira-Dias, F., Marques, P., Pinto, A. and Bhatti, A. (2013b), "Performance evaluation of retrofitting strategies for non-seismically designed RC buildings using steel braces", Bul. Earthq. Eng., 11, 1129-1156. 
